\title{
Worldview-Building Potential of Ukrainian ABC Bukwar Textbooks
}

Ganna Valentynivna Izyumtseva

Follow this and additional works at: http://digitalcommons.cedarville.edu/education_theses

Part of the International and Comparative Education Commons

\section{Recommended Citation}

Izyumtseva, Ganna Valentynivna, "Worldview-Building Potential of Ukrainian ABC Bukwar Textbooks" (2013). Master of Education Research Theses. 57.

http://digitalcommons.cedarville.edu/education_theses/57 
TEXTBOOKS

\begin{abstract}
A thesis submitted in partial fulfillment for the requirements of the degree

Masters of Education
\end{abstract}

By

GANNA VALENTYNIVNA IZYUMTSEVA

Degree of Specialist, English Language and Foreign Literature, National

Dragomanov Pedagogical University of Ukraine, 2002

M.A. English Language and Literature, National Dragomanov Pedagogical

University of Ukraine, 2003

2013

Cedarville University 


\begin{abstract}
Izyumtseva, Ganna V. M.Ed., Educational Department, Cedarville University, 2013. Worldview-Building Potential of Ukrainian ABC Bukwar Textbooks.
\end{abstract}

The research study examined the worldview foundation undergirding the content of Soviet and contemporary Ukrainian ABC Bukwar textbooks (hereinafter referred to as the Bukwar) to define whether, if at all, contemporary Bukwar has moved from the Soviet control beliefs, whether it stimulates the formation of a new conceptual vision of reality, necessary for building democratic society and formation of a new human resource. To conduct the study, I employed the grounded theory as a leading theoretical paradigm. The analysis has identified the position of Soviet and contemporary Bukwars on the metaphysical-epistemological questions (different positions on the question of metaphysics and epistemology result in different worldviews). The results were juxtaposed and interpreted in relation to the cultureworldview dynamic system; the role of Bukwar as a component of this system was identified. The findings reveal that contemporary Bukwars have moved from a totally atheistic foundation; however, the worldview base undergirding their content remains incoherent. The research study discusses the findings in the context of cultural and political transformations occurring in Ukrainian society. 


\section{Table of Contents}

Chapter One: Introduction to the Study ....................................

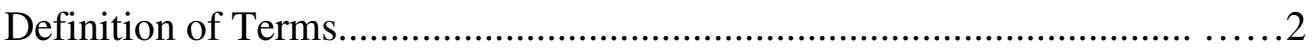

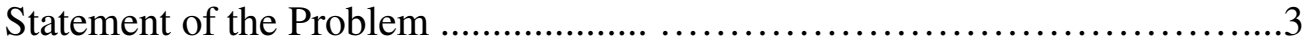

Scope of Study and Delimitations ............................................................ 7

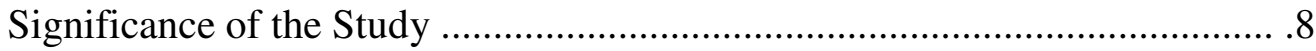

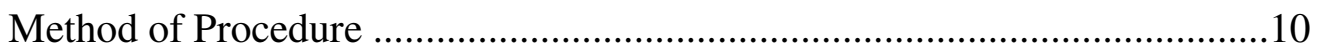

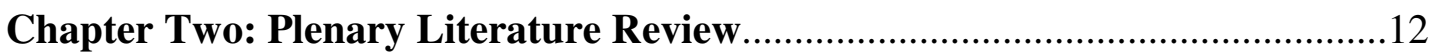

When All the Pieces Come Together............................................................12

Worldview-Culture-Textbook Discourse Solidarity ...................................14

The Worldview Mechanism........................................... 18

The Discourse Capacity to Stimulate a Worldview Transformation...........27

The Bukwar Discourse Capacity to Produce Particular Human Resource.....35

Chapter Three: Methodology .............................................................4 43

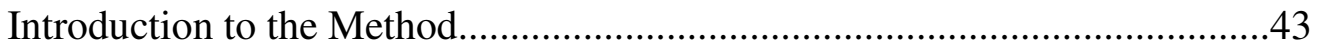

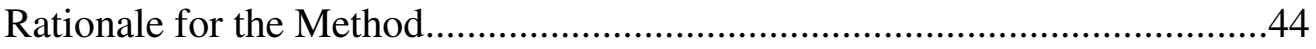

Sample.............................................................. 45

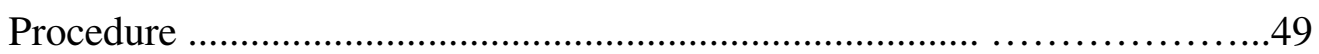

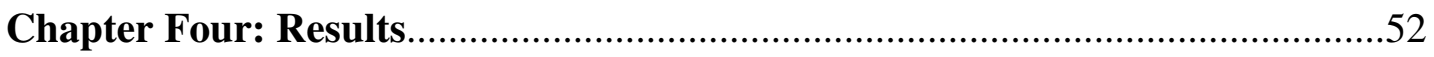

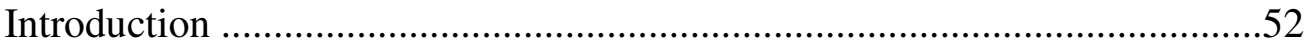

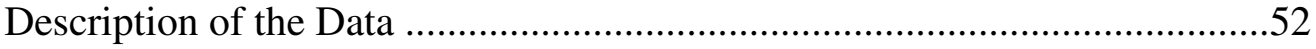

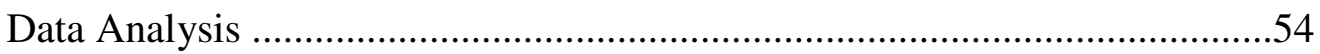

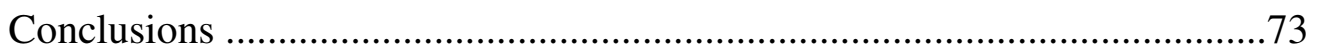

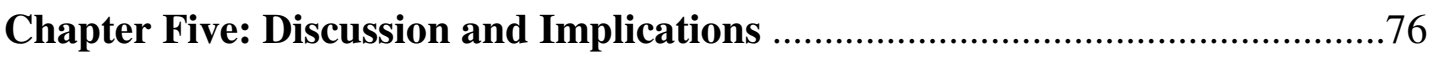


Introduction.

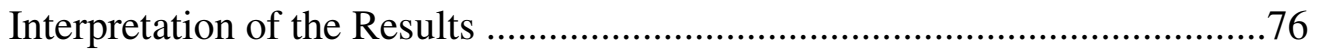

Potential Applications of the Findings.................................................... 78

Biblical Integrative Component and Implications......................................79

Relation of the Results to Theory and Other Literature $\ldots \ldots \ldots \ldots \ldots \ldots \ldots \ldots . .80$

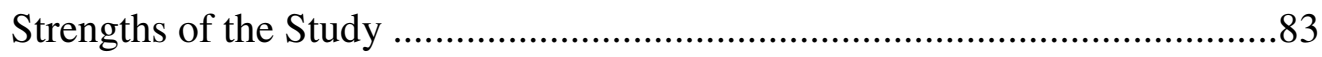

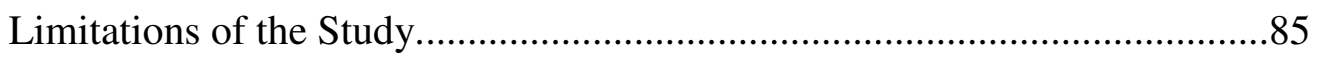

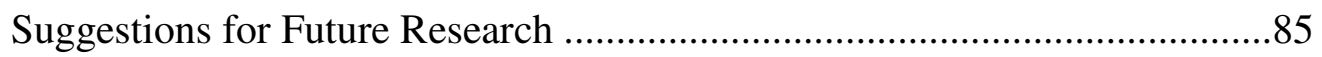

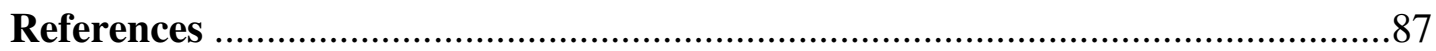




\section{Acknowledgements}

When I think of all blessings that God has given me, I want to ask God echoing Job, "What am I that You magnify me, and that You are concerned about me?" Opportunity to get the degree from Cedarville University I consider to be a blessing and a rare privilege. To have educational experience like I have had at Cedarville was my hidden desired wish. It seemed so unrealistic that I have never let myself even think about it. When God has given me this chance through Dr Stephen S. Gruber, I could hardly believe it.

Dr Stephen S. Gruber is a man of vision, expertise, understanding, and commitment. To find people like him is a rare blessing. Over four years he patiently has been standing behind my educational process, advising me, teaching me, and providing for me. With great joy and tears in my eyes I look back at my educational journey with Dr Stephen S. Gruber, the man of God and my supervisor, and I regret profoundly that it is almost over. From all my heart I thank Dr Stephen S. Gruber for his dedication, for investing his time and knowledge in me.

I am grateful to my dear sister in Christ Bonnie Hailey for her gift of friendship, for her support and investment in me. She mentored me, and in many ways has prepared me to this educational adventure. She generously shared her life and heart with me taking her time for proofreading and debriefing. I am thankful to her that she understood the importance of this education for me and without hesitation has become a part of my dream project. 
I want to extend great appreciation to Robert and Cherry Grimshow, Ronald and Kay Howard, educators and dear friends of mine, for sharing their experience and knowledge, for their encouragement and enthusiasm, for being there for me when I was far from my family, for helping me to enjoy every minute of my educational adventure.

I am thankful to all professors who taught me and led me through years of my education at Cedarville University. The part of their wisdom in visible or invisible manner is present in lines or between lines of this research study.

I owe a great debt to my dear family, to my husband and children, who made all possible and impossible to help their mama to live out a dream. They deep love and faith in me were a source of inspiration, and made me believe that I could do it. Without their patience and support this research study would have never gotten completed. 


\section{Chapter One: Introduction to the Study}

In 1991 (after the collapse of the Soviet Union) Ukraine again re-appeared on the world geographical map as an independent state. However, it was the Orange Revolution of 2004 that "put Ukraine back on Europe's mental map" (Velychenko, 2007, p. 1). The Ukrainians of my generation witnessed a series of striking political events in Ukrainian history (2004-2005) termed Orange Revolution that, regardless of polar interpretations of these events by contemporary politicians, did reawaken the national spirit. What is even more striking, 5 years later Ukrainians find that this term is deleted from the Ukrainian history school textbooks. Experts explain that it is done to avoid needless politicization of students (“'Orange Revolution' has Disappeared from New History Textbooks", 2010).

This case has challenged many Ukrainians and reminded them about the relationship between the knowledge included into the school textbooks and official powers. Since the textbooks, as Apple (1992) points out, "signify - through their content and form - particular constructions of reality" (p.4), rewriting of the content of Ukrainian school textbooks directly leads to and signifies about reconstruction and redefining the reality Ukrainians live in. I witnessed myself the time of Perestroyka, the USSR collapse, and the events that led to Ukraine's independence, the Orange Revolution, and all dramatic post-revolution events. I was attracted to the idea that I could explore the school textbooks content and see what direction Ukrainians as a nation was heading again.

I have chosen as a focus the analysis of the primary school literacy textbooks. For nearly seventy years in Ukraine the school textbooks served as the tool for 
implementing of Soviet control beliefs, thus molding generations into the faithful defenders of the communist ideals. It is time to see, whether the conceptual lens the contemporary textbooks, and particularly, the primary school literacy textbooks provide allow educating the generation of Ukrainians seeing the world differently.

\section{Definition of Terms}

Competency Based Education. Competency Based Education focuses on outcomes of learning. CBE addresses what the learners are expected to do rather than on what they are expected to learn about (Richards \& Rodgers, 2001, p. 141).

Control beliefs. Control beliefs are one's most basic convictions regarding the world and morality (Phillips \& Okhom, 1996/ 2001, p. 23).

Culture. Culture is the way in which the People understand and express their world and how the People understand themselves in their relation to their world (Freiré \& Macedo, 1987, p. 60).

Developed socialism. A period in history of the Soviet Union between 1964 and 1985 (Hosking, 1993).

Discourse. Following Foucault (e.g. 1972, 1980), we define 'discourse' as any semiotic mode of signification - spoken, written, visual, and so on, or as a form of social practice (cf. Halliday, 1978) (as cited in Bishop \& Jaworski, 2003).

Ideology. Ideologies are representations of aspects of the world which can be shown to contribute to establishing, maintaining and changing social relations of power, domination and exploitation (Fairclough, 2003).

Language. Language is a system of linguistic signs interconnected and interdependent (Saussure, 1916/ 1995). 
Perestroika (reconstruction). Method of M. Gorbachov (the last head of state of the Soviet Union) used to reform the Soviet system in the period between 1985-1991 (Kundan, 2003).

Society. Society is an identifiable population, centripetally-oriented, acting in accordance with a distinctive culture, and emotionally bound through common language and symbolic experiences (Hoebel, 1972, p. 702).

Worldview. A conceptual scheme, by which we, consciously or unconsciously place or fit everything we believe and by which we interpret and judge reality (Nash, 1992, p. 16).

\section{Statement of the Problem}

When the communist bloc disintegrated (1989-1991), Ukraine (the former Soviet Union Republic) declared its independence and had to take a huge step forward in its independent democratic political and economic development. According to Wilson (1995/ 2002), subsequent years of transition are characterized by political and economic insecurity, and gradually diminishing national selfassurance in the midst of growing feelings of genuine regret for the lost of "unbreakable Union of freeborn republics, great Russia has welded forever to stand" (a popular among Soviet people line from "The State Anthem of the USSR" written by Mikhalkov in 1944). Existing mind dualism is expressed by saying that is attributed to the leader of Ukrainian Socialist Party Moroz, "Anybody who does not regret the collapse of the USSR has no heart; anybody who wants to restore the Union has no head" (Wilson, pp. 191-192). 
Presidential elections - the Orange revolution V. Yushchenko's election of 2004-2005, and the V. Yanukovich's election of 2010 - made existing mind dualism even more visible and more alive than ever. The Orange Revolution (November and December of 2004) demonstrated a pro-democratic shift in Ukrainian mindset. Nevertheless, next 2010 Presidential election that resulted in election of opposition candidate Viktor Yanukovych obviously demonstrated a swing to the other end of the thought-belief-hope spectrum of Ukrainians. As contemporary historian Kuzio (2011) points out, "the 2010 election of Viktor Yanukovych was less a victory for him than a defeat for 'orange' forces” (p. 88). Nowadays, the Party of Regions represents the strongest and the most influential political force in Ukraine. Apparently, while Ukraine is open to change, there remain strong feelings of resistance to all new; the Soviet beliefs are still alive and well in grass roots' as well as politicians heads.

The socio-economic conditions in Ukraine stimulated reforms in the area of education. According to the Millennium Development Goals (2005), guidelines for Ukraine's long term development (until 2015), this phenomenon can be explained by at least two factors. First of all, it is largely due to the fact that education is "the key to a country's capacity to move towards in innovation-based model of economic development" (p. 10). In addition, the need to increase the quality of education has become an issue of concern for almost all Ukrainians used to enjoy high standards in education. There is a general understanding among Ukrainians that high quality education should continue to be a priority.

Reform Strategy for Education in Ukraine (2003) shows that the reform in educational sector of Ukraine involved introduction of new educational standards; updating and development of curricula; revision of textbooks; and adopting adequate 
approaches to education. A competency-oriented approach to education has replaced the old Soviet approach to education that mainly relied on rote memorization and suppressed critical thinking skills. As Ovcharuk and Voytov (2003) notes, the new approach to education was expected "to promote the formation of a new value system in society" (p 28). All of this is connected with revising of published textbooks and designing new textbooks. Thus, over the course of recent years, a great deal of Soviet and contemporary educational materials have been revised, many textbooks studied and upgraded. Upgrading has involved the removal of ideological doctrines, revision of school history and literature programs, the rehabilitation of long forgotten personalities, new textbook design for recently introduced subjects as well as other changes. As a result, the content of school textbooks has been changed in many ways. Cultural knowledge (facts, rituals, examples and role models, etc.) their content incorporates brings new narratives about ultimate issues of life: Who am I? Why do I exist? What will become of me? Does God exist? Can I know Him? What is truth? Why do I know that this is truth? How can I know what is good and what is evil? Why does evil exist? How should I live? All these questions in essence are worldview questions. By providing answers to such questions, textbooks through their content shape students' vision of reality; it in its turn, as Smart (1983) points out, "forms a background" (p. 4) to the lives they lead, define their thinking and actions.

The study (Makarevych and Bezrohov, 2005) has shown that textbooks posses the worldview building potential which is equal to the formative power of religious texts. Ukrainians cannot ignore this fact; otherwise they will never move from, as Remnick (1993) defines Soviet regime, a "soulless utopia” (p. 361) implemented by Lenin back in 1917. It is important to understand that political changes in Ukraine or 
even the change of the course of the whole country may not mean the progress if the very foundation of society remains the same. This very foundation is a worldview, and its power should be recognized.

Although all dramatic changes in a post-Soviet part of the world are widely acknowledged, and become the centre of interest of many researchers (Kaplan, 2005, 2007; Kuzio, 1998, 2001, 2002, 2006, 2011; Lieven, 1994; Polyzoi \& Nazarenko, 2004; Pingel, 2006; Wilson 1995/ 2002; Zajda, 2003, 2005, 2007), their true face remains hidden, since there appears to be no studies on the worldview foundation of the post-communist Ukrainian textbooks. In other words, there are no studies on how the content of contemporary Ukrainian textbooks addresses basic worldview questions. Native and foreign scholars (Janmaat, 2007; Popson, 2001; Wanner, 1998; Zajda, 2009) have undertaken in-depth studies of the content of Ukrainian history textbooks and stressed their role in a nation-building process; however, the worldview base of Ukrainian school textbooks remains unexplored.

This research study will critically scrutinize content of the Ukrainian ABC Bukwar textbooks seeking to answer the following questions: What worldviews do these textbooks provide? How does the content of the Ukrainian ABC Bukwar textbooks address basic worldview questions? How, if at all, does Bukwar through its texts represent worldview shift (if there is one)? How the vision of the world provided by the contemporary Bukwar is different from the one taught twenty years ago during the Soviet Union times?

\section{Scope of the Study and Delimitations}

I am analyzing the content in prescribed Ukrainian Soviet and contemporary Bukwar to see how it addresses basic worldview questions. For the purpose of our analysis, we have selected copies of Vashulenko \& Skrypchenko (1985), as well as 
Horetskyi, Kiryushkyn \& Shanko' (1985) Bukwars that were printed in the Union of Soviet Socialist Republics (the USSR) on the eve of Perestroyka (1985).

1. Букварь : Учеб. для 1-го кл. трехлет. нач. шк. / Н. Ф. Скрипченко, Н. С. Вашуленко ; Худож. А. Б. Жуковский и др., 112 с. ил., 2 отд. л. «Разрезной азбуки» 24 см, 4-е изд. Киев: Рад. шк., 1985. /translation: Skrypchenko, N. F. , \& Vashulenko, N. S. (1985). Bukwar (4th ed.) . Kiev: Radyanska Shkola.

2. Букварь / [В. Г. Горецкий, В. А. Кирюшкин, А. Ф. Шанько] 127 с. ил., 1 отд. л. ил. 22 см 5-е изд., перераб. М.: Просвещение, 1985. /translation: Horetskyi, V. G., Kiryushkyn, V. A. , \& Shanko, A. F. (1985). Bukwar (5th ed.). M.: Prosveshcheniye.

These versions of Bukwar were provided by the CPSU school reform; they were developed, tried, refined, approved by the CPSU, and finally adopted by schools as leading elementary literacy textbooks of Soviet school at the peak point of socialism in the USSR. Thus, as I believe, they accurately meet the requirements of Soviet system of education and embody the ideas of Soviet regime. This all makes them exemplary in terms of worldview filling, and thus turn them into the object of our special interest. Interestingly, Vashulenko and Skrypchenko published their Bukwar in 1978. It has been reprinted for 30 times since then, and, in fact, its updated version has remained the leading Bukwar in contemporary Ukrainian schools.

The set of contemporary Ukrainian Bukwars we analyze within the frame of this paper comprises Vashulenko \& Vashulenko (2012) Bukwar and Pryshchepa \& Kolesnychenko (2010) Bukwar:

1. Вашуленко М.С. Буквар: Підручю для загальноосвіт. навч. закл.І М.С. Вашуленко, О.В.Вашуленко. - К.: Видавничий дім «Освіта», 2012. /translation: Vashulenko, M. S., \& Vashulenko, O.V. (2012). Bukwar. K.: Osvita Publishing House. (The 2011 all-Ukrainian contest of 1-4 grade (primary school) textbook manuscripts winner). 
2. Прищепа К.С. Буквар / К.С.Прищепа, В.І. Колесниченко. - К.:Генеза, 2010. /Pryshchepa, K. S., \& Kolesnychenko, V.I. (2010). Bukwar. K.: Heneza. (The 2011 all-Ukrainian contest of 1-4 grade (primary school) textbook manuscripts winner).

Our choice of contemporary Ukrainian texts is limited to Bukwars - winners of the All-Ukrainian contest of 1-4 grade (primary school) textbook manuscripts held by the Ministry of Education and Science of Ukraine in 2011. All schools around Ukraine use these versions of Bukwar in a current 2011-2012 academic year.

The scope of the study involves the identification and comparison of worldview basis of prescribed Ukrainian Soviet and contemporary Bukwars; explanation of new discourses, omissions; interpretation of specific illustrations from worldview standpoint. Though teachers may use different resources, the textbooks used for this study belong to the core curriculum and are used by most of the students. Thus, Ukrainian Soviet and contemporary Bukwars that do not belong to the core curriculum are not the part of this analysis.

\section{Significance of the Study}

As in the former Soviet Union, the use of textbooks in independent Ukraine is widespread and officially promoted. Both teachers and students rely much on them. For teachers they organize what to teach, for students - what to learn. Although different resources (digital or printed, other than prescribed textbooks) which the teacher finds helpful can be used to intensify learning process, textbooks, as Apple (1992) points out, "for better or worse, dominate what students learn" (p.6).

It should be emphasized that to get on the teachers' or students desk, a textbook goes through the process of careful selection and accurate assessment. In response to the state order and, in particular the Ministry of Education and Science, 
Youth and Sport of Ukraine, the textbooks are written and their manuscripts are submitted to the All-Ukrainian contest carried out by the subject expert panels. Having been confirmed by and having been given the approval stamp of the Board of the Ukrainian Ministry of Education and Science, Youth and Sport, the contest winning materials are (according to a special ministerial order) published and used in schools. With such highly centralized educational system in Ukraine, the school textbook content is likely to have a thorough impact on the spiritual and social development of growing generations of Ukrainians who are " $25 \%$ of population but $100 \%$ of the future" (Lickona, 2003, p. xxiii).

Bukwar is the elementary school literacy textbook used in the first grade of all Ukrainian schools. Very often it becomes the very first book that a child studies himself. Bukwar introduces the child to the concept of a native language, and helps the child to take first steps toward conceptualization of reality he belongs to. The way how the content of Bukwar addresses the worldview questions shapes his vision of the world, defines his mode of thinking and behavior. Since declaration of independence of the Ukrainian state, Ukrainian education has been pursuing a goal of educating a new, different from a Soviet type, man. The point is that it will fail again, if the worldview base undergirding the content of Ukrainian textbooks remains the same as it was 22 years ago, when Ukraine was one of 15 republics of the USSR.

Thus, textbooks may become the powerful tool for either building up the future of the nation or destroying it. This makes the content of Ukrainian school textbooks, and in particular Bukwar significant and interesting object of research.

The following investigation is conducted in three steps. Conceptualization of the term worldview for the purpose of the current study initiates the study. 
Following on from that, the worldview-Bukwar content relation within a cultural framework is determined. Finally, the paper provides the analysis of selected data and interprets results.

The study is expected to reveal the worldview base undergirding the content of Soviet and contemporary Ukrainian Bukwar, and define whether, if at all, contemporary Ukrainian Bukwar has moved from the Soviet control beliefs, whether it promotes and stimulates the formation of a new conceptual vision of the world, necessary for building democratic society.

\section{Methods of Procedure}

I have examined a full literature review of the topic of interest. In Kyiv, Ukraine I used sources from Dragomanov National Pedagogical University Library (бібліотека Національного педагогічного університету імені Михайла Драгоманова) and the Vernadsky National Library of Ukraine (Національна бібліотека України імені В.I. Вернадського). It is worth noting that Dragomanov National Pedagogical University, as a major higher education establishment preparing teaching personnel, possesses one of the best collections of educational resources. The Vernadsky National Library of Ukraine (Національна бібліотека України імені В.I. Вернадського) is the largest library in the country. I also worked with books purchased from bookstores. I searched for available research from online databases such as Academic Search Complete, Ebsco, OhioLink, Education Full Text, Education Research Complete, PsychInfo, ERIC, Google Books, and Google Scholar. I have consulted available Soviet and contemporary Bukwars, those which belong and do not belong to core curricula. 
This research study is a qualitative research. To conduct the study, I use the grounded theory as a leading theoretical paradigm. Grounded theory as an inductive method allows a researcher to discover what the book offers. "It strives to unfold patterns of understanding or worldviews that have guided content selection and modes of presentation" (Pingel, 2010, p. 70).

In addition to grounded theory, the study uses hermeneutic, linguistic, and discourse analysis. The central methodological strategy is to use the synergy produced by the combination of above methods to discover how content of selected for analysis Bukwars addresses five worldview questions:

1. Metaphysics: Is reality essentially spiritual or material?

2. Philosophical anthropology: Are human beings inherently spiritual or material?

3. Axiology: What is valued?

4. The problem of evil: What is wrong?

5. Ethics: How should we then live?

(Gruber \& Baumann, personal communication, July 11-15, 2011) 


\section{Chapter 2: Plenary Literature Review}

\section{When All the Pieces Come Together}

To see, look worldviewishly. As Walsh and Middleton (1984) rightly point out, "when we look at a culture, we are looking at the pieces of a puzzle" (p. 18). To interpret such pieces, to understand why people perceive and respond to reality in a particular way, one should study their worldviews - "the deepest level presuppositions (assumptions) upon which they base their lives" (Kraft, 1996, p. $52)$.

In Ukraine on Epiphany day after the Divine Liturgy Orthodox believers cut a hole in the ice and take dips in freezing water (Boychenko, 2011).

Mahsoun N. R. Choudhury, Programme Officer, Communication, Wildlife Trust of Bangladesh shares that, when a local man is killed by a tiger, his wife is thrown out of her husband's family, with whom she has been living since marriage (Chowdhury, 2011).

The May 2012 Ukrainian local digital RT Channel broadcasted about a "five fingers stone" construction located near Kusoty village the Buryatia (Russia) in the midst of vast steppe and hills. They showed how locals pray by the rock (in Buryatia shamanism is still practiced).

While on the surface these stories seem to be just cultural pieces taken from the lives of different communities, in-depth they are the embodiments of people's basic assumptions about reality and their interpretation depends on the worldviews that have the leading role in the life of these communities. If, for instance, "the worldview of a people conditions them to believe that the universe is operated by a number of invisible personal forces largely beyond their control, this will affect both 
their understanding of and their response to "reality"' (Walsh \& Middleton, 1984, p. 36). This explains why for some people water is much more than just a chemical liquid with a chemical formula $\mathrm{H} 2 \mathrm{O}$; why superstitions may have such drastically tragic power over people's lives; why people pray by the rock and how a stone can plead to gods, and why the shaman's ecstasy products still may decide peoples' destiny. Just as the Thomas Kuhn's (1996) famous duck-rabbit ambiguous image can be seen and interpreted differently the reality is seen and interpreted differently by people possessing different worldviews.

On the term. In his book Worldview: The History of a Concept, David K. Naugle (2002) provides an exhaustive discussion of the history and contemporary use of the term worldview. For the purpose of the present work, I will point out that the term worldview (the German term Weltanschauung (Welt-means world and Anschauung - German for view) was coined by the philosopher Immanuel Kant and that it originally meant simply “... our intuition of the world [weltanschauung]” (as cited in Miller \& Guthrie, 2001, p. 36). In the retrospect of time and in the context of different scientific fields, such as philosophy, anthropology, history, theology, linguistics, and due to the efforts of a galaxy of scientists, such as Kuyper (1880, 1898 ), Hoebel (1954), Whorf (1956), Kluckhohn \& Strodbeck (1961), Kroeber (1963), Sapir (1964), Wallace (1970), Kuhn (1970), Geertz (1973, 2000), Walsh \& Middleton (1984), Olthius (1985), Bush (1991), Nash (1992), Wright (1992), Sire (1997, 2004), Phillips \& Okholm (2001), Hiebert (1985, 1994, 1999, 2008), Skott (1996), and Kraft $(1989,1995,1996,2005 b, 2008)$ the concept of worldview has received various interpretations.

It should be noted that there are some interpretations that explain the term in a broader way. 
The term worldviews refers to any ideology, philosophy, theology movement, or religion that provides an overarching approach to understanding God, the world, and man's relations to God and the world. Specifically, a worldview should contain a perspective regarding to each of the following ten disciplines: theology, philosophy, ethics, biology, psychology, sociology, law, politics, economics, and history. (Noebel, 2001, p. 2)

There is also "a long-standing tendency to equate "ideology" with "an oversimplified worldview" (Sunderlin, 2003. p. 16); in other words, the terms worldview and ideology are used interchangeably.

However, regardless of a variety of opinions, the major points of convergence of existing interpretations of the concept, as the literature on the issue suggests, can be assimilated to three leading ideas: first, worldview is, by using James Olthius' (1985) terminology, “a vision 'of' life and the world, and simultaneously a vision 'for' life and the world"(p. 3); second, in the bottom of a worldview there are the most basic convictions regarding the world and morality, one's "control beliefs" (Phillips \& Okholm, 1996/ 2001, p. 23); and third, worldview delineates our thinking paradigm (Wright, 1992) and is "implicit in almost every act" (Wallace, 1970, p.

143). These ideas determine our understanding of what worldview is and how it is related to the object of our research.

\section{Worldview-Culture-Textbook Discourse Solidarity}

A vision of and for life. In his 1973 discussion of religion as a cultural system, Geertz explores a double nature of a model of reality. He distinguishes between an “' $o f$ ' sense and a 'for' [italics added] sense of model of reality” (p. 93), and points out that they are two aspects of one and the same basic concept. Regardless of existing between two aspects inseparability, their distinguishing is necessary as it allows a researcher to see that the models of reality are both the 
extrinsic sources of information and the shapers of that information. Geertz (1973) terms this phenomenon the "dual focus" (p. 93) phenomenon.

This phenomenon has serious implications for the conception of the worldview. It suggests that the worldview is a source of knowledge about reality, and at the same time it shapes what and how an individual should think about reality or view it. As Olthius (1985) puts it, the worldview is "a vision 'of' life and the world [which] is simultaneously a vision 'for' life and the world . . . it both describes what we see, and stipulates what we should see" (p.3). As a vision of reality, the worldview gives a picture of the world, just as it is (descriptive function); and as a vision for reality, it provides a normative framework of a world, as it should be (its normative function). Olthius also specifies the worldview character. It is individualized; however, at the same time it preserves its communal nature. On the one hand, individuals are bearers of worldviews. Although worldview is not in our DNA, there is no a single individual without it. On the other hand, the worldview integrates within itself ideas, feelings, values and goals, and presents itself as a unified and specific version of reality grouping its adherers together in a community.

A culture-worldview dynamic system. On a cultural scale, according to Hiebert's (2008) model of a culture, the worldview constitutes implicit hidden layer of the culture and "defines the way in which people view the world, determines their value; it establishes the basic tempo and rhythm of life" (p. 32), and undergirds the other two layers: explicit (belief systems), and sensory (cultural products, behavior patterns, signs, rituals). According to Kraft (1996), the worldview is "included in culture as the structuring of the deepest-level presuppositions on the basis of which people live their lives" (p. 52). He associates intricate connection between culture 
and worldview with a river flow. What we see is only the surface of the river; its largest part we cannot see, it is invisible. But whatever happens on the surface of the river is affected by this invisible flow. Although Hiebert (2008) holds that the depth layer is "particularly resistant to manipulative attempts to change it from the outside" (p. 329), such scientists as Kraft (1996) and Luzbetak (1993/2000) underline the interconnection of cultural layers, pointing out that the hidden layer shapes the visible layer; and the visible layer in its turn may initiate and stimulate the change of the hidden one.

This phenomenon is of paramount importance for our investigation, as it is on the surface of the culture that the textbooks content finds its place. To see the rationale behind this statement, the textbooks content should be understood as the collection of discourses included in the pages of textbooks and used to educate students.

\section{A school textbook discourse as a component of the culture-worldview}

dynamic system. The notion of discourse has been approached from different perspectives. Gee (2011) considers it to be the "language-in-use" (p. 8); for Fairclough (1992), "it is language use, whether speech or writing, seen as a type of social practice (p. 28). Foucault (1972) treats discourses as "practices that systematically form the objects of which they speak. Of course, discourses are composed of signs; however, what they do is more than use these signs to designate things (p. 54). Such position is supported by Candlin (1997) who says that "we may go on to discuss the constructive and dynamic role of either spoken or written discourse in structuring areas of knowledge and the social and institutional practices 
which are associated with them" (p. ix). Jaworski and Coupland (1999) speak of discourse even in a wider contest.

Discourse reaches out further than language itself. When we think of discourse in the wider context of communication, we can extend its analysis to include non-linguistic semiotic systems (systems for signaling meaning), those of non-verbal and non-vocal communication which accompany or replace speech or writing [...] non-verbal discourse modes include painting, sculpture, photography, design, music and film. (Jaworski \& Coupland, 1999, p. 7)

Proceeding from authoritative explanations of the term given above, for the purpose of the present paper, I employ the term discourse in a wide sense of the concept. Following Foucault (e.g. 1972, 1980), we define 'discourse' as any semiotic mode of signification - spoken, written, visual, and so on, or as a form of social practice (cf. Halliday, 1978) (as cited in Bishop \& Jaworski, 2003).

It is essential to understand that, according to this conception, any printed text or picture is considered to be a discourse. In line with F. de Saussure's (1916) concept of language dichotomy introduced in Course in General Linguistics, discourse refers to one of language aspects parole (speech) (p. 14). It is a manifestation of langue (a language system as a system of signs interconnected and interdependent) in a social intercourse. When we use the language to communicate the massage, according to Benveniste, "we leave the domain of language as a system of signs and enter into another universe, that of language as an instrument of communication, whose expression is discourse (as cited in Mills, 2004, p. 4). Discourse is a manifestation of language system; therefore, when it comes to discourse, it comes to the language as a whole.

In the light of preceding reflections, it is safe to say that the texts included in the school textbooks are discourses that are embodiment of a language system itself. 
Moreover, as significative embodiment of langue (a language system), they find their place on a surface of the culture and function as a component of the cultureworldview dynamic system. As any other constituents of a surface layer, the school textbook mode of discourse is not neutral; it is shaped by the hidden layer of the culture (a particular worldview); in its turn it may be used to initiate and stimulate its (worldview) transformation. To grasp the full purport of this argument, one has to understand the worldview mechanism, how worldviews are transformed and can be changed. To discuss this matter shortly is the next on my agenda.

\section{The Worldview Mechanism}

The nature of control beliefs. To begin with, let us discuss the nature and the role of " "control beliefs' that are at the very bottom of any worldview ... one's most basic convictions regarding the world and morality" (Phillips \& Okhom, 1996/ 2001, p. 23). To broaden our understanding of this issue, let us look at first at the etymology of words basic and beliefs. Klein (1965/1969, p. 161) points out that Old English form of the noun belief is geleafa (belief, faith); it is formed from West Germanic word ga-laubon (to hold dear, esteem, and trust). Partridge (1958/1977) leads us to the same understanding of word providing explanation through Latin word confidere - "to have trust or confidence, yields "to confide"" (p. 1048). The noun base from which an adjective basic is formed means bottom, foundation, or pedestal. The word is adopted from Old French bas (depth), comes from Greek word basis (a stepping, a step, a stepping-stone, a pedestal) (Klein, p. 151; Partridge, p. 222). From this brief survey, it seems clear that beliefs are products of faith; the most cherished faith that assumes our trust and dependence; they are basic in the sense that they are the deepest, starting, and fundamental faith structures. 
Further speculation about basic beliefs as products of faith leads us to Kuyper (1931/1999) and Dooyeweerd's (1955/1997) understanding of terminal function of faith. Everything starts from "real, genuine faith" (Kuyper, p. 131) that is induced by the inner being of a human being, which does not have anything with superstitions and existence of which should be recognized by science. In this respect, as Miller and Guthrie (1998/2001) explain, there is no neutral reality. every human being may be considered to be religious. Faith lies deep down at the level where our reasoning comes to an end. In this sense faith may be considered to be ultimate; it is this ultimate faith that the worldview basic beliefs regarding the world and morality are rooted in.

To grasp in what sense the worldview basic beliefs are controlling structures, it is important to look at Wolterstorff's explanation of the term control beliefs elaborated in his book Reason within the Bounds of Religion. However, we should bear in mind that Wolterstorff uses a term theory to mean science, what German word Wissenschaft implies as systematic knowledge. Although Wolterstorff shares his view how control beliefs function in the case of religion and science, nevertheless, the corollaries he makes help us not only to grasp the meaning of the term control beliefs but to see the worldview mechanism as it is.

"Control beliefs" are certain beliefs as to what constitutes an acceptable sort of theory on the matter under consideration. ... Control beliefs function in two ways. Because we hold them we are led to reject certain sorts of theories some because they are inconsistent with those control beliefs; other because though consistent with our control beliefs, they do not comport well with those beliefs. (Wolterstorff, 1984, p.15)

The above quote suggests that individual's basic beliefs regarding the world and morality not only constitute individual theoretical frame but they work as a 
security or controlling system of the individual weighing and filtering knowledge the individual receives. The individual will reject everything that conflicts or does not comport well with his control beliefs; and at the same time the individual will accept everything that "satisfies the control beliefs"(Wolterstorff, 1984, p.95).

The role of control beliefs. Within a worldview framework, as Miller and Guthrie (1998/2001) point out, control beliefs frame worldviews by shaping responses to the real life questions. Naugle (2002) asserts that these questions as a worldview itself are inseparable from human existence. They come out from within a human being; they are the "why, whence, and whither" (p. 10) questions of life. The wording and number of these questions may vary from author to author but their content always remains the same. Wilhelm Dilthy's worldview questions:

What I am supposed to do in this world, why I am in it, and how my life in it will end? Where did I come from? Why do I exist? What will become of me? (as cited in Naugle, 2002, p.83)

James Sire's (2004) worldview questions:

1. What is prime reality - the really real?

2. What is the nature of external reality, that is, the world around us?

3. What is a human being?

4. What happens to a person at death?

5. Why is it possible to know anything at all?

6. How do we know what is right and wrong?

7. What is the meaning of human history? (Sire, 2004, p. 19)

Dr Gruber and Dr Baumann (2011) formulated five worldview questions:

1. Axiology: What is valued?

2. Metaphysics: Is reality essentially spiritual or material?

3. Philosophical anthropology: Are human beings inherently spiritual or material?

4. The problem of evil: What is wrong?

5. Ethics: How should we then live? (Gruber \& Baumann, personal communication, July 11-15, 2011) 
Knight (1982) asserts that these questions have to do with different aspects of metaphysics and epistemology. Since epistemology and metaphysics "stand at the base of human thought and activity" (26), whole thinking and actions of a human being are totally shaped by what his basic beliefs are regarding origin and development of the universe, regarding the purpose it is tending to (cosmological aspect of metaphysics); conceptions of and about God (theological aspect of metaphysics); about humanity (anthropological aspect of metaphysics), relation and interaction between mind and body, moral status of a man, limits of his freedom, nature of his soul, if there is one; regarding the nature of existence (ontological aspect of metaphysics); and finally regarding nature, sources, and validity of knowledge (epistemology).

Knight's worldview questions can be presented in the following way:

1. Metaphysics

Cosmological aspect of metaphysics

a. How did the universe originate and develop?

Theological aspect of metaphysics

b. Is there God?

c. Is so, is there one or more than one?

d. What are the attributes of God?

e. If God is both all good and all powerful, how is it that evil exists?

f. Are there such beings as angels?

g. Are there evil powers?

h. If so, what is their relationship to God?

Anthropological aspect of metaphysics

a. What is the relation between mind and body?

b. Is there interaction between mind and body?

c. Is mind more fundamental than body, with body depending on mind or vice versa?

d. What is humanity's moral status?

e. Are people born good, evil, or morally neutral?

f. To what extent are individuals free?

g. Do they have free will, or are their thoughts and actions determined by their environment and inheritance?

h. Does an individual have a soul?

Ontological aspect of metaphysics

a. Is basic reality found in matter or physical energy (the world we can sense), or it found in spirit or spiritual energy? 
b. Is it composed of one element (e.g., matter or spirit), or two (e.g., matter and spirit), or many?

c. Is reality orderly and lawfully in itself, or is it merely orderable by theorists?

d. Is it fixed and stable, or is change its central features?

e. Is this reality, unfriendly, or neutral in regard to humanity?

3. Epistemology

a. Can reality be known?

b. Is truth relative or absolute?

c. Is knowledge subjective or objective?

d. Is there truth independent of human experience?

4. Axiology

e. What is of value?

\section{Ethics}

a. Are ethical standards and moral values absolute or relative?

b. Do universal moral values exist?

c. Does the end ever justify the means?

d. Can morality be separated from religion?

e. Who or what forms the basis of ethical authority?

f. What should I do?

Worldviews are generated by this metaphysical-epistemological "mind's quest" (Naugle, 2002, p. 10). Commonly people are oblivious to this fact, as a fish that lives inside a glass bowl but is oblivious to the fact that the water surrounds it. However, within a worldview frame, whether people are conscious of it or not, an individual will reject everything that conflict or does not comport well with the control beliefs of his worldview.

When his metaphysical-epistemological equilibrium is challenged by reality, the controlling system of his worldview (control beliefs) is alerted, and the process of weighing the intruding reality begins. The intruders may be accepted on the grounds that they fit control beliefs. In this case, individual's position on the metaphysicalepistemological questions remains generally the same. However, when intruding reality does not fit control beliefs, it will be either rejected, or control beliefs themselves will induce the revision of individual's metaphysical-epistemological position. 
Miller (2001) points out that worldviews developing in the faith-life experience tandem should function as an open system. It means that from time to time individuals should allow the developments that do not comport their control beliefs to induce the revision of individual's metaphysical-epistemological position. Not allowing the critical revision of the basic beliefs underlying a particular worldview interferes with the worldview modification or its correction. Wolterstorff (1984) rightly underlines the fact that, if the Congregation of Inquisition had allowed the revision induced by scientific development, particularly astronomical ones, the history of religion, definitely, would have taken a different course.

Control beliefs and the worldview transformation dynamics. The concept of control beliefs allows understanding the worldview transformation dynamics. Taken in consideration two aspects of worldview character, I will look at the worldview transformation dynamics at the level of community and at the level of individual.

A worldview transformation dynamics at the level of community. At the level of community, the worldview transformation dynamic may be exemplified by the elementary model of the process of worldview transformation offered by Kraft (1996). Kraft's model comprises three idealized states: (a) the old steady state; (b) the crisis situation; (c) the new steady state.

The initial state (the old steady state) embodies the state of idealized equilibrium between the hidden and surface cultural layers of society. It is a state of idealized metaphysical-epistemological harmony when external cultural reality is shaped by and satisfies control beliefs constituting the worldview base of the culture. Note, that we do not discuss whether control beliefs are true. From outside, cultural 
reality may seem weird or totally wrong and evil. We do not judge it. The point is that there is equilibrium between hidden and surface cultural layers.

The "crisis situation" indicates a global challenge of the discussed above equilibrium by some radical external factors. As a result, the hidden cultural layer or to be more exact the control beliefs constituting the base of the leading worldview of community are challenged community either resist intruding non comporting reality, or revise already existing basic beliefs. In case of slight correction, the worldview modification of community takes place. In cases, when replacement of basic beliefs is needed, the comunity experiences the worldview crisis, proceeding with a subsequent conversion from one faith to another; the worldview shift takes place and a new vision is adopted. It is Kraft's third state; it identifies the ideal outcome of the crisis. As the worldview is a faith based system, viability of a new vision depends on adequate support and training on the part of a new faith community.

It should be stressed that, since individuals are bearers of worldviews anyway, a replacement of a worldview foundation of any society is a matter of replacement of control beliefs of individuals of this society. It is complicated and multidimensional phenomenon.

History proves theory. Ii is interesting to see, how history itself proves the above theory. For instance, in a course of history, Ukrainians have survived two worldviews crises, both of them were induced from outside. The first worldview crisis was induced by a forceful mass scale Christianization of the Kievan Rus population (Ukrainians and Russians) (988 AD). For the Kievan Rus prince Volodymyr (Vladimir) it looked like a wise political step. Making attempts to strengthen his authority and to unite Kievan Rus lands, he forced pagan population to 
adopt a new religion against their will. Thus, people were baptized and in the majority of cases, the act of baptism was the act of survival that had nothing to do with a Christian sacrament. However, the Kievan Rus society adopted the novelty and became a part of the Christian world. Although polytheism persisted in the country for a long time, theistic control beliefs, after all, became leading in society. In a subsequent historical period, Ukrainian lands were divided into two Ukraines (Galicia and Dneeper) and partially Catholicized; however, at the moment of Bolsheviks' October Revolution (1917) Ukrainians held theistic control beliefs.

Coming of Bolsheviks initiated the second worldview crises situation. The replacement of existing control beliefs was a guarantee, a cornerstone of sustainability of the world's first socialist state (established in 1922) and building the Communist society. The Bolsheviks have achieved the goal by means of red terror mass arrests and executions of bearers of old control beliefs, annihilation of everything not compatible with values of new Bolshevik culture, and educating a right type of man by teaching growing generations new control beliefs.

Boyd (2000) makes a good point in his investigation saying that Soviet children of the post-World War II were the first generation to grow up entirely after the revolution, and to be educated in a pure spirit of socialism. It was a human resource grown on principles of dialectical materialism, atheism.

Remnick (1993) reminds that except for the fact that, to gain the allegiance of the population, during World War II, Stalin temporary put aside the war on religion and used Orthodox Church for consolidation of country, any manifestation of religiosity or faith was considered to be alien to Soviet understanding of reality; ministers were imprisoned, believers were prosecuted as enemies of state. The 
proceeding generations grew in a culture where the Soviet atheistic reality they lived in was the reality as it should be; no question about that.

Boyd (2000) mentions in his paper that one of the first Communist songs of a young Soviet state was "Bce выше" / "Ever Higher". Words were written by P. German, music composed by Y. Науіt. It says that "Нам разум дал стальные рукикрылья, / А вместо сердца пламенный мотор". This means that "reason has given us iron hands-wings, and instead of heart it has given us a fiery motor". It made me think that the lines of the song embody the idea that is completely contrary to what God promises in Ezekiel 36:26 (NIV), to "remove from you your heart of stone and give you a heart of flesh". The song was written in 1920. Only a few generations later the ideas of that song have become the reality for many people. Post - WWII generations were no more creations of God, they were products of evolution with "fiery motors" instead of hearts. At that point, as for me, the replacement of control beliefs was successfully completed. Taking in consideration that, as Remnick (1993) points out, the Communist Party of the Soviet Union was of a totalitarian character, "it controlled the government and controlled everything" (p. 509) control beliefs established as a result of the worldview shift were expected to go from strength to strength as long as the Party existed.

It is reasonable to ask, what will happen then, if a novelty is rejected? This may lead to other outcomes, for instance, as Kraft (1996) points out to extinction of community or its submersion. Submersion of culture occurs when it outwardly adopts a novelty, although inwardly tends to preserve the same worldview. Extinction may happen when members of community lose integrity, and for instance, through intermarriages incorporate other cultures. 
A worldview transformation dynamics at the level of individuals. At the level of the individual, when his idealized metaphysical-epistemological equilibrium (Kraft's first state) is challenged by reality, the controlling system of his worldview (control beliefs) will either accept intruders or resist them. If intruders are accepted, the worldview remains generally the same. However, if there is a gap between what his worldview basic belief system incorporates and intruding reality, the controlling system ought to either resist non comporting reality, or revise the basic beliefs the worldview incorporates. In case of slight correction, its modification takes place. In case of a replacement of basic beliefs, the individual experiences the worldview crises (Kraft's second state), proceeding with a subsequent conversion from one faith to another; the worldview shift takes place and the individual adopts new vision of reality (Kraft's third state). As the worldview is a faith based system, viability of a new vision depends on adequate support and training on the part of a new faith community a converted person ought to adhere now. For instance, for a secular person developing a Christian worldview, crises results in act of repenting which is expected to proceed to sanctification (growing in Christlikeness) encouraged by the church. Otherwise, a person may return to his old ways.

\section{The Discourse Capacity to Stimulate Worldview Transformations}

Let us go back to the passage where we discuss interconnection of cultural layers. It was found that the hidden layer of the culture not merely shapes its visible layer; the visible layer may initiate and stimulate the change of the hidden one. Given that control beliefs are in the heart of the worldview mechanism, it is safe to say that it is control beliefs the hidden cultural layer incorporates that shape a visible layer of the culture. By saying that the school textbook discourse as any other 
constituent of a surface layer is shaped by the hidden layer of the culture, and in its turn may be used to initiate and stimulate its change, we mean that the school textbook discourse is shaped by the control beliefs that are in the bottom of the worldview of this particular culture, and in its turn it may become the intruder challenging the control beliefs, initiating the worldview crises, and after all, the worldview shift. To grasp the full purport of interaction between the school textbook discourse and worldview, one has to understand the discourse capacity to embody worldview, to articulate the worldview it incorporates, as well as to shape and produce particular ways of thinking, doing and being in the world. I will discuss this phenomenon in its connection with such central linguistic topic as the languageworldview relationships and Freiré and Macedo's (1987) concept of reading the word and the world.

Discourse capacity to embody worldviews. We have discussed earlier in the work in what sense discourse is a manifestation of the language as a whole. Such approach to discourse is allowing us to understand the discourse-worldview relationship as the language-worldview relationship.

The language-worldview relationship finds its recognized explanation in the works of Wilhelm von Humboldt, Franz Boas, Edward Sapir, and Benjamin Whorf. Their works present forward the idea of interconnection of language and speakers' worldview. In his paper "Über den Dualis" presented to the Prussian Academy in 1827, Humboldt expresses the thought that language determines the way of seeing the world.

Die Sprache ist aber durchaus kein bloßes Verständigungsmittel, Language is by no means a mere means of communication, but the mirror of the mind and the world view of the speaker". (as cited in Konrad Koerner, 2000, p. 10) 
In his 1911 Introduction to Volume I of the Handbook of American Indian Languages written in 1908, Franz Boas follows Humboldt's mode of thinking and highlights reciprocal interconnection between language and thought. In line with Humboldt and Boas, the Sapir-Whorf principle of linguistic relativity claims that "all observers are not led by the same physical evidence to the same picture of the universe, unless their linguistic backgrounds are similar, or can in some way be calibrated (as cited in Konrad Koerner, 2000, p. 13).

All above said implies that it is mother tongue that determines the way people perceive and conceptualize the world. Different languages not merely incorporate different worldviews, but that every distinctive language calls into being concepts that without it would never exist, creates particular conceptual lens and makes its speakers to see the world through it. As Pütz and Verspoor (2000) put it, a "language can affect the society, influencing and even controlling the world-view of its speakers" (p. ix).

Regardless the controversy and critique the Sapir-Whorf principle of linguistic relativity has caused, findings of recent cognitive research (Rosh, 1978; Lakoff, 1987; Lakoff \& Johnson, 1980/2003; Langacker, 1991, 1999, 2001; Fauconnier \& Turner, 1996, 1998, 2002; Gruyter, 2006; Evans \& Green, 2006; Dobrovol'skij, 2011) strongly confirm Wilhelm von Humboldt, Franz Boas, Edward Sapir, and Benjamin Whorf's ideas. If approached from an angle of cognitive linguistics, the language-worldview relationship should be interpreted in terms of categorization and conceptualization - the basic cognitive processes and at the same time the most central cognitive abilities of a man. As Boldyryev (2001) explains, categorization helps a man to organize the knowledge about reality by dividing it in 
categories; i.e., distinguishing within it groups, classes, and categories of analogical objects and events on the basis of perceived similarities. Conceptualization, in its turn, is a process and ability to process the information about the world; it results in formation of concepts - the abstract bits of knowledge about the world acquired by individual in a process of interaction with environment.

Generalizing various aspects of reality concepts exist in a form of abstract entities of different degree of complexity, and can be looked at as the constructions constituting cognition (Leontyev, 1974; Potapenko, 2002); where cognition should be understood both as a cognitive process and a product of this process (Boldyryev, p. 10). Concepts constitute the conceptual (mental) picture of the world of individuals and represent the content of their cognition (Kubriakova, 1996).

There is a large body of literature Serebrianikov, Kubriakova, \& Postovalova, 1988; Lakoff, 1990; Lakoff \& Johnson, 1980/2003; Wierzbicka, 1980, 1999; Talmy, 2000; Langacker, 1991, 1999, 2001; Dobrovol'skij, 2011) proving that concepts are verbalized in language through words, propositions, utterances, different communicative segments, etc. "Syntactic, morphological, and phonological representations are basically conceptual. ... Sounds and utterances are the input and output of cognitive processes" (Croft \& Cruse, 2004). In this way, language and cognition are inseparable. Language presents itself not only as a means of comprehending reality, ordering and preserving knowledge about it, but also as a verbalized representation of the consciousness content, and consequently as a verbalized representation of a set of basic beliefs regarding the world and morality. This set of basic beliefs is nothing but worldview. 
Discourse capacity to articulate worldviews. As we have previously

discussed, control beliefs frame the worldview by shaping responses to basic worldview questions (metaphysical-epistemological questions). When the consciousness content is verbalized, the worldview speaks out through words and reveals itself through the discourse by articulating responses to basic worldview questions. Interesting how Kuyper expressed this idea in 1931, when cognitive linguistics even did not exist.

Every kind of faith has in itself an impulse to speak out. In order to do this it needs words, terms, expressions. These words must be the embodiment of thoughts. Those thoughts must be connected reciprocally not only with themselves but also with our surroundings, with time and eternity. (Kuyper, 1931/1999, p. 131)

The reverse side of this phenomenon that is of prime importance for our investigation is that we may determine the worldview base (a set of basic beliefs regarding the world and morality) of a discourse by scrutinizing the discourse it undergirds, and examining the responses to basic worldview questions it articulates. However, the more texts the clearer picture of the world. As Humboldt holds, only the collection of texts provides a realistic picture of the world (as cited in Trabant, 2000, p. 33).

\section{Discourse capacity to produce particular ways of thinking, doing and}

being in the world. It is essential at this point of investigation to explore discourse capacity to shape and produce particular ways of thinking, doing and being in the world. In other words, to explore its capacity to shape the human resource in accordance to worldview base undergirding it. For this, the present study draws on Freiré and Macedo's (1987) concept of reading the word and the world; "reading the word implies continually reading the world" (p. 23). I employ this concept to 
emphasize that the process of reading is not only the process of becoming literate, but it assumes embracing particular knowledge about reality, and, as Gee (2011) points out, knowledge of "what is 'normal' and not; what is 'acceptable' and not; what is 'right' and not; what is 'real' and not; what is the 'way things are' and not; what is the 'ways things ought to be' and not'" (p. 4).

While reading, if the act of reading is understood as an act of "reading the world" (Farer, 1987, p.23), the basic beliefs regarding the world and morality the discourse incorporates work as intruders. If intruders do not comport well with the control beliefs that are in the bottom of the readers' worldview, they will experience the worldview crisis situation. The reader's worldview controlling system will either resist the non comporting reality, or revise the existing control beliefs or replace them. Thus, some modification of worldview or even its shift may be expected as an outcome of the process of reading. However, it is not a final outcome yet. According to Knight (1982), different positions in conception of truth and reality determine people's value systems; value systems impact the decisions; this, taken all together finds reflection in behavior and practices:

Worldview is the very skeleton of concrete cognitive assumptions on which the flesh of customary behavior is hung. Worldview, accordingly, may be expressed, more or less systematically, in cosmology, philosophy, ethics, religious ritual, scientific belief, and so on, but it is implicit in almost every act." (Wallace, 1970, p. 143)

Thus, the act of reading is by no means the innocent intellectual amusement. Through reading discourse opens the mind and the heart of individuals and shape those in accordance to worldview base undergirding it.

In summarizing the above it can be emphasized that a discourse presents itself as an embodiment of a worldview with particular control beliefs in the bottom of it. These control beliefs can be revealed by scrutinizing and analyzing the discourse. In 
a process of reading the assumptions about reality the discourse incorporates may work as intruders challenging the equilibrium of an individual's worldview controlling system or even initiating the worldview crisis situation. The metaphysical-epistemological shift will result in formation of different control beliefs, and consequently, different worldview. Adopted worldview position will determine the value systems, will delineate the mode of thinking and, after all, will find reflection in behavior and practices.

Discourse does matter. History proves that the worldview shift can be stimulated and a desired type of human resource can be produced by providing the members of society with a discourse incorporating particular worldview. To provide an example, I will use the Bolsheviks' regime. I want to point out that changing the discourse was a key point of their strategy.

When Bolsheviks came in power, Ukrainians were illiterate in a modern understanding of this word; however, they were not detouched from the Bible. In the Introduction to his Bukwar printed in 1634, V. Burtsov pointed out that at first Bukwar was considered to be a tool to learn how to read and understand Scriptures. Later on learning to read began to pursue also mundane aims, but, generally, Bukwars' content had remained to be the embodiment of Christian worldview up to Bolshevik's coming in 1917. For instance, in Tulupov's Bukwar (1909) in “The Song of a Plougher" we read, "With a quiet prayer / I will plough and sow, / Give me, God, / the bread -my treasure" (p. 151). Furthermore, in a poem "Sowing", we find, a farmer prayed to All-Merciful Christ and went in the field to sow" (p. 151).

Bunakov's Bukwar (1913) teaches, "Without God's will not a hair of your head will fall to the ground. Orphans are God's children" (p. 21). "God holds the world, science helps to survive" (p. 22). 
In Lev Tolstoy's Bukwar (1912) we read that "it is God's will for everything" (p.52), “we should know God's will” (p. 53), "people pray to God for help” (pp. 58, $65,85)$. It is interesting to note that Tolstoy's Bukwar was reprinted several times; and it was even used during the first years of Soviet power.

When the Bolsheviks came to power, among the very first documents Lenin signed (December 1919) was the Decree on total liquidation of illiteracy. A new system of orthography, simple and easier, was introduced. It had to become an instrument of implementation of appropriate control beliefs. Its adoption was actually a struggle for a new culture and a new man.

Lenin's idea that literature should not only reflect reality but also should help to change it (Lenin, 1905, "Party Organization and Party Literature") was put into practice. The method of Socialist Realism has become a principle artistic method of Soviet literature. It not only depicts reality from the dialectical materialism standpoint but also shapes and builds up a new type of man, a pure atheist who is faithful to the ideals of the Communist Part, that is to say, a Soviet type of man.

On the ruins of old educational system, a new single, all-embracing compulsory education system is established. School textbooks and generally all children's books become a mighty means for implanting the socialist convictions (Krupskaya, 1931, "Children's Books: A Mighty Weapon in the Struggle for the Socialist Upbringing of our Children"). New school curriculum that is based on a right worldview is developed, and is expected to instill in growing generations of the state of Soviets right vision of reality. From then on for 70 years, generation after generation, children would absorb right control beliefs on a subconscious level. 
As Bolsheviks' practice has shown, it is possible to replace control beliefs by transforming the discourse and by introducing to selected discourse as many members of society as it is possible, and as long as it is possible.

Another example is from Olster' (2005) overwhelming survey of development of the world's major languages. He reminds us the story how in the third century AD Christians advanced the conversion of the Egyptian people. First, since the Egyptian language was more complex, they had to create new language - the Coptic language; second, they have translated into Coptic their doctrinal texts; third, they let them to be widely read by individuals and in the Egyptian Church. In conclusion of the story, Olster writes, "Coptic became a major channel for the development of the Christian doctrine" (p.133). Of course it was will of Almighty God, however, if we carefully think of this historical event in a context of interplay of cultural layers, we should admit that the strategy of the third century AD Christians was based on twofold interdependence between discourse and worldview. Since none of tools existing on the surface of Egyptian culture at that time could meet their need to challenge a deep layer of Egyptian culture, they had gone as far as creation of a totally new sign system to produce a suitable discourse capable of shaking and reshaping the worldview foundations of locals. In the worldview terms, new discourse had to incorporate adequate conceptual arsenal to present a particular vision of the world and to stimulate a control beliefs replacement. In fact, as history proves, the outcome was equal to their expectations. With God's help, through provided discourse Egyptians were exposed to a different vision of the world that has challenged and initiated a shift of control beliefs underpinning their worldview and many of them came to Christ. 


\section{The Bukwar Discourse Capacity to Produce Particular Human Resource}

All above examples from human history proves existing interdependence of discourse that is found on the surface of the culture and worldview that constitutes the hidden layer of the culture. In even more general terms, we may say that it is a dynamic interdependence and solidarity between the surface and deep layers of culture. Due to the discourse capacities the deepest hidden layer of culture translates itself into a surface one, allowing at the same time interventions into the deepest level of culture. The capacity of discourse to embody worldview, to articulate the worldview it incorporates, and to produce particular human resource, turns it in an effective (as history proves) instrument of such intervention. Understanding of this phenomenon is critical and does much to illuminate the role of school textbooks mode of discourse and especially the Bukwar mode of discourse in a process of shaping and reshaping worldview foundations of growing generations.

Bukwar as a worldview project. Russian scholars Makarevych and Bezrohov (2005) compare the power of textbooks with the power of religious texts. They point out that textbooks are capable of impacting and shaping students' worldviews:

Создает рисунок на оконном стекле, сквозь которое ученик смотрит на мир (и на свое отражение). Стереть этот рисунок невозможно, равно как и не видеть его./ Creates a picture on a window glass, impossible to erase or ignore. It is through this picture, that the child sees the world (together with his her own reflection) (p. 80).

Uchaykina (2005) considers textbooks to be particular worldview projects pursuing particular goals:

мировоззренческие системы, содержащие в себе элемент идеального проектирования общественных структур, которые направлены на радикальное преобразование и совершенствование человеческого мира./ 
worldview projects comprising elements of ideal projection of social structures that aim at radical transformation and improvement of a world the man lives in. (Uchaykina, p.492).

According to Apple (1992), knowledge textbooks incorporate is selected and organized according to someone's vision, and it is according to this vision that all aspects of human existence are interpreted.

Above said suggests that Bukwar as a textbook functions as a worldview project pursues particular goals. Bukwar is the very first elementary school textbook. It introduces the child to his culture in its many-sidedness, and to the world, known and not known to him. The authors construct particular characters on the pages of Bukwar intending to embody in them appropriate almost ideal traits of character, needed for a growing generations. They construct the picture of an appropriate world and model an appropriate attitude to it and vision of it, expecting to cultivate and implant appropriate attitude and vision.

Factors intensifying Bukwar's discourse capacities. As we have discussed in Chapter 2, the texts included in the school textbooks are considered to be discourses. As significative embodiment of a system of language, they find their place on a surface of the culture among other discourses and function as a component of the culture-worldview dynamic system; therefore, there is interdependence between the Bukwar mode of discourse, and the worldview that constitutes the hidden layer of the culture. As any other constituents of a surface layer, the school textbook mode of discourse is not neutral; it is shaped by the hidden layer of the culture (a particular worldview); in its turn it may be used to initiate and stimulate its (worldview) transformation. 
As we have already discussed, the capacity of discourse to embody worldview, to articulate the worldview it incorporates, and to produce particular human resource turns it in an effective instrument of intervention into the deepest hidden level of culture. As any discourse, the Bukwar mode of discourse possesses this power of influence too. As any discourse, Bukwar's discourse presents a particular position on the metaphysical-epistemological questions; but what seems to be underestimated is that implantation of this particular position is ensured by a number of factors.

1. School education in Ukraine is compulsory; Bukwar is a part of prescribed curriculum. It means that students must go to school and must master the Bukwar content to be able to move to the next educational level.

2. The learning process takes place in relatively closed groups; it maximizes learning, because the members of a group are persistently introduced to Bukwar's discourse during a whole academic year.

3. School involves children into relationships "delimited and constrained by the rules of schooling which position teacher, text, and student in hierarchical levels of power and authority" (Luke, C., De Castell, S., \& Luke, A., 1983, p.125); consequently, teacher's interpretation of Bukwar, as well as what is written in Bukwar acquires power and authority.

4. At school students must master what is purposefully selected for them, as Olson (1980) puts it, "what the society takes to be "true" and "valid" knowledge" (p. 191).

5. Bukwar is a collection of texts; this factor, according to Humboldt (as discussed in Chapter 2) must ensure the coherence of the vision of reality Bukwar speaks out. 
6. Given that child's capability to adopt "moral standards early in life is universally recognized" (Wilhelm and Firmin, 2008, p. 186), Bukwar as the very first elementary school literacy textbook is likely to produce the most stable and lasting effect.

Thus, in the process of education, through the act of reading, the child's control beliefs are either confirmed or challenged; and when the change is stimulated and enforced, all listed above factors will ensure its proper and unified outcome.

I agree with Dr Futrell's (as cited in Mulenga, 2011) opinion that there are stakeholders in society behind the worldview who ensure that the proper worldview is taught. This suggests that there are stakeholders in society behind teaching and learning process who ensure that the proper worldview is taught at schools. This implies that, regardless of what it may seem on the surface, everything what the Bukwar discourse presents serves one purpose. This is what actually stands behind the mundane fact that every school textbook is censored by the state and is recommended or licensed by an appropriate governmental body, though we may never think of it. In addition, as Van Dijuk (1993) stresses, the school textbooks mode of discourse is turned into ideological battlefield, in "a tool for manipulation one strategic ways to change the mind of others in one's own interests" (p.254). It is another reason why, what is written, how it is written, and finally, why it is included in a textbook is strategically important.

A full theoretical analysis of the discourse capacity in relation to the worldview-culture dynamic system is beyond the scope of this research study. Our brief discussion of these processes brings us to conclusion that, within a general cultural framework, the Bukwar discourse finds its place on the surface of culture. As other discourses, it embodies and is shaped by control beliefs constituting the 
worldview base of the culture. The worldview base of society reveals itself through the discourse of Bukwar by articulating responses to basic worldview questions. As I have already outlined, through the act of reading child's control beliefs are either confirmed or challenged. The assumptions about reality that Bukwar's discourse incorporates may work as intruders challenging the equilibrium of child's worldview controlling system. They even may initiate the worldview crisis situation - the metaphysical-epistemological shift. If the change is stimulated, it will be enforced by factors ensuring the formation of appropriate control beliefs, and consequently, appropriate worldview. Adopted worldview position will determine the value systems, will delineate the mode of thinking and, after all, will find reflection in behavior and practices.

As other components of a surface layer, it can be used to impact the hidden cultural layer. Moreover, the influence of Burwar's discourse compared to influence of other surface components of culture is much greater due to general capacities of discourse and factors ensuring implementation of desired control beliefs. It should be stressed again that, as we have already discussed, it is individuals that are bearers of worldviews; therefore, a replacement of a worldview foundation of any society is a matter of replacement of control beliefs of individuals of this society. To see the scale of influence of this textbook, it is necessary to understand that almost everyone in this country starts its literate life with Burwar.

The vision of reality of generations of Ukrainians, past generations and future generations, are shaped by the discourse of Burwar. Burwar embodies the dream of a man and the world as they should be. Above factors working together produce, I 
believe, synergetic effect capable of reshaping the hidden layer of culture, and indicate that the battle for new Ukraine starts on the pages of Bukwar.

\section{Literature Results:}

- A worldview is a vision of life and the world, and simultaneously a vision for life and the world.

- The worldview constitutes implicit hidden layer of the culture, shapes the visible layer that, in its turn, may initiate and stimulate the change of the former one.

- The texts included in the school textbooks are considered to be discourses. As significative embodiment of a system of language, they find their place on a surface of the culture and function as a component of the culture-worldview dynamic system.

- There is interdependence between the Bukwar mode of discourse that is found on the surface of the culture among other discourses, and the worldview that constitutes the hidden layer of the culture.

- As any other constituents of a surface layer, the school textbook mode of discourse is not neutral; it is shaped by the hidden layer of the culture (a particular worldview); in its turn it may be used to initiate and stimulate its (worldview) transformation.

- Control beliefs (the most basic convictions regarding the world and morality) frame the worldviews by shaping the responses to the most basic questions people may have about reality and themselves, and account for the dynamicity of a worldview mechanism. Adoption of a new worldview is the matter of replacement of control beliefs. 
- The capacity of discourse to embody worldview, to articulate the worldview it incorporates, and to produce particular human resource, turns it in an effective (as history proves) instrument of intervention into the worldview foundation of the culture.

- A replacement of a worldview foundation of any society is a matter of replacement of control beliefs of its members.

- Within a general cultural framework, the Bukwar discourse finds its place on the surface of culture; and as other discourses, it embodies and is shaped by control beliefs constituting the worldview base of the culture.

- The worldview base of society reveals itself through the discourse of Bukwar by articulating responses to basic worldview questions.

- Through the act of mastering the Bukwar content, the child's vision of the world is either confirmed, transformed or replaced, in case of replacement, the new worldview is adopted.

- The formative power of Burwar's discourse compared to influence of other surface components of culture is intensified by factors ensuring implementation of desired control beliefs. It is these factors in tandem with discourse capacities that produce some synergetic effect capable of reshaping the hidden layer of culture and formation of a particular human resource.

- What basic beliefs undergird Bukwar's discourse (what is written, how it is written, and finally, why it is included) is strategically important.

- Construction of a new society is not merely the matter of changing of behavior and practices but it is rather a great deal the matter of changing of worldview. Ukraine will fail again, unless Ukrainians understand that all 
changes they desperately need are a matter of moving from old vision of reality, and that the battle for new Ukraine starts on the pages of Bukwar. 


\section{Chapter 3: Methodology}

\section{Introduction to the Method}

This research examines how the content of Soviet and contemporary Ukrainian Bukwars addresses basic worldview questions. The worldview questions emerged from the theory detailed in Chapter 2:

6. Axiology: What is valued?

7. Metaphysics: Is reality essentially spiritual or material?

8. Philosophical anthropology: Are human beings inherently spiritual or material?

9. The problem of evil: What is wrong?

10. Ethics: How should we then live?

(Gruber \& Baumann, personal communication, July 11-15, 2011)

As discussed in Chapter 1, this study is a qualitative research. It employs grounded theory method that consists in "systematic, yet flexible guidelines for collecting and analyzing qualitative data to construct theories 'grounded' in the data themselves" (Charmaz, 2006, p. 2).

Thornberg and Chamaz (2011) describe grounded theory as an inductive, iteractive, interactive, and comparative method. Inductive character of grounded theory means that researchers begin by studying data from which they develop abstract concepts. Iteractive character of grounded theory implies moving between data collection and conceptualization. Such approach allows asking more focused questions of the data involving researcher in interactive activity. The whole process is based on making systematic comparisons to construct the concepts. A grounded theory emerges inductively from the study, "One begins with an area of study and what is relevant to that area is allowed to emerge" (Strauss \& Corbin, 1990, p. 23).

As research shows (Jenner \& Titscher, 2000), grounded theory is linked with other methods of qualitative studies taking up a dominant position among them. This 
allows the present research study to benefit from synergy produced by employment of hermeneutic, linguistic, and discourse analysis.

Although grounded theory allows conceptualization of data-based assumptions, hermeneutic analysis intensifies endeavors to discover the intended meaning of the text, and "all the implications or unconscious meanings contained in the pattern (or type) he is teaching" (Stein, 1994, p.43). It helps also to uncover the underlying assumptions and the connotations which a textbook content may evoke in the student's mind and helps to find out what patterns of understanding or worldviews have guided textbook content selection.

Jenner and Titscher (2000) note that a grounded theory text analysis allows investigation of linguistic categories; however, in addition to this, linguistic analysis, as Stein (1994) points out, provides precise understanding of words and terminology within the "norms of the language" (p.50), gives deeper insight into the choice of words itself.

The discourse analysis contributes in a current research by revealing sociopsychological characteristics of the author of the text, allowing to identify "what information, groups and events the author values, takes for granted, or regards as unimportant" (Pingel, 2010, p. 71).

\section{Rationale for the Method}

My rationale proceeds from the grounded theory character. The study of Bukwars' worldview foundation requires an employment of inductive method. Inductive method allows examining the data from an unbiased perspective. It is especially significant for this study, because to see a real worldview situation presented through Bukwar's content, I should begin a study with no theory I wish to fit the data. I believe that such approach creates a fresh perspective on the 
phenomenon under consideration inviting unbiased feedback. However, it should be stressed that my own worldview creates unavoidable bias.

Iteractive character of grounded theory allows a researcher to work with details and at the same time to see the picture in general. There is uninterrupted link between data collection and conceptualization that, I believe, contribute into development of a good theory.

Interactive character of grounded theory allows a researcher to have more freedom with asking the questions. This allows discovering data which does not "fit", however, is important for the study.

By allowing systematic comparisons, the grounded theory turns the study in a dynamic process inviting new insight in the research process itself.

Thornberg and Charmaz (2011) underline that grounded theory allows constructivist approach to this method, which allows viewing "both data and analysis as social constructions and takes into account conditions of their production" (p. 41) that I find very useful for analysis Ukrainian Bukwars published during different regimes.

\section{Sample}

In the former Soviet Union the number of published Bukwars was limited. Bukwars as the rest of school textbooks were free of charge and were distributed via school libraries. By the end of the academic year students had to return Bukwars to their school library. Ukraine has inherited a system for the centralized supply of textbooks via school libraries from the former Soviet Union. It made an attempt to transit to the free sale of textbooks in 1998. However, Ovcharuk and Voytov (2003) 
assert that transition was never implemented and a relevant decision was cancelled a year later in 1999; once again the policy for centralized supply of textbooks and training aids through school libraries was reapproved. Taking in consideration that schools are supplied only by the textbooks that have undergone the process of authorization (appointment of seals and certificates by the Ministry of Education and Science of Ukraine), only thoroughly selected Bukwars are used at schools. These Bukwars, in fact, constitute the population of the study. It is rather small, as the number of Bukwars used at schools is limited. For the purpose of the present study, the following copies of Burwars are selected. Thus, the sample includes:

\section{Soviet Bukwars}

1 Букварь : Учеб. для 1-го кл. трехлет. нач. шк. / Н. Ф. Скрипченко, Н. С. Вашуленко ; Худож. А. Б. Жуковский и др., 112 с. ил., 2 отд. л. «Разрезной азбуки» 24 см, 4-е изд. Киев: Рад. шк., 1985. /translation: Skrypchenko, N. F. , \& Vashulenko, N. S. (1985). Bukwar $\left(4^{\text {th }}\right.$ ed.). Kiev: Radyanska Shkola.

2 Букварь / [В. Г. Горецкий, В. А. Кирюшкин, А. Ф. Шанько] 127 с. ил., 1 отд. л. ил. 22 см 5-е изд., перераб. М.: Просвещение, 1985. /translation: Horetskyi, V. G., Kiryushkyn, V. A. , \& Shanko, A. F. (1985). Bukwar (5 ed.). M.: Prosveshcheniye.

contemporary Bukwars:

3 I Вашуленко М.С. Буквар: Підручю для загальноосвіт. навч. закл.І М.С. Вашуленко, О.В.Вашуленко. - К.: Видавничий дім «Освіта», 2012. /translation: Vashulenko, M. S., \& Vashulenko, O.V. (2012). Bukwar. K.: Osvita Publishing House. (The 2011 all-Ukrainian contest of 1-4 grade (primary school) textbook manuscripts winner).

4 Прищепа К.С. Буквар / К.С.Прищепа, В.І. Колесниченко. - К.:Генеза, 2010. /Pryshchepa, K. S., \& Kolesnychenko, V.I. (2010). Bukwar. K.: Heneza. (The 2011 all-Ukrainian contest of 1-4 grade (primary school) textbook manuscripts winner). 
Sample criteria. Specific criteria were used to select the sample of textbooks in this study. The sample was to be (a) a part of the core curriculum, (b) authorized textbooks (approved by authority and recommended for usage all over Ukraine), (c) Soviet Bukwars were to be published on the eve of Perestroyka (1985); contemporary Ukrainian Bukwars were to be winners of the 2011 All-Ukrainian contest of 1-4 grade (primary school) textbook manuscripts.

Sample rationale. Contemporary Ukraine was one of the 15 republics of the former USSR (the Union of Soviet Socialist Republic). The system of the USSR was highly centralized and controlled by the Communist Party of the Soviet Union (CPSU). Soviet Bukwars used for the purpose of the present research study were published in the USSR at the end of a period of so-called developed socialism. This period is identified with Leonid Brezhnev's regime (the General Secretary of the Central Committee of the CPSU, presiding over the USSR from 1964 until his death in 1982). The CPSU' goals for education of this period is formation of comprehensive young men possessing dialectical-materialistic worldview, firmly believing in overall victory of Communism, promoting the ideas and ideology of the Party, and having active life position (Materials of XXV Congress of CPSU, 1976). The goal of the CPSU has enforced a school system reform which required modernization of the curriculum and textbooks content. In response to a challenge, in 1978 scholars Vashulenko and Skrypchenko published a probe-copy of their Bukwar. In 1980 it was officially approved and recommended for usage all over the Soviet Socialist Republic Ukraine.

Brezhnev's demise (1982) was followed by a short term regimes of other Soviet leaders that mainly supported a previous course of the country. However, they could not prevent growing skeptical attitudes toward the concept of developed 
socialism that soon has evolved into Perestroyka (1986) and finally in the USSR defragmentation (1991). Perestroyka stimulated revision, updating and developing new Bukwar, as the Soviet ones did not suit a new course the country.

Prior to Perestroyka, in schools of the Ukrainian Soviet Socialist Republic children learned how to read mainly using the texts of Vashulenko and Skrypchenko (1985), as well as Horetskyi, Kiryushkyn and Shanko' (1985) Bukwars. As I have briefly outlined above, these versions of Bukwar were provided by the CPSU school reform; they were developed, tried, refined, approved by the CPSU, and finally adopted by schools as leading elementary literacy textbooks of Soviet school at the peak point of socialism in the USSR. Thus, as I believe, they had accurately met the requirements of Soviet system of education and embodied the ideas of Soviet regime. This all makes the texts they include exemplary in terms of worldview filling, and thus turn them into the object of our special interest.

Ukraine declared its independence in 1991. For twenty two years Ukraine has been persistently trying to move from Soviet past and to restore the spiritual health of the nation. This goal is making new demands of education. In 2011, with the purpose of improving the quality of education, the Ministry of Education and Science held the All-Ukrainian contest of 1-4 grade (primary school) textbook manuscripts. Vashulenko and Vashulenko (2012) Bukwar and Pryshchepa, and Kolesnychenko (2010) Bukwar are winners of the contest. They have undergone the approval procedure, have met all necessary requirements, and are offered to elementary school students. In a current 2011-2012 academic year schools around Ukraine mainly use the texts these Bukwars to teach children how to read. This explains our choice of 
contemporary Ukrainian textbooks. They can be considered to be the best in all respects.

\section{Procedure}

Within the frame of the present research study, I examine the texts included in the sampled textbooks. Since, as research (Jenner and Titscher, 2000) shows, the application of grounded theory requires no specific methods of data collection, moreover, it does not require that data collection was completed before analysis begins, I started my analysis with initial reading of texts. Then I read the texts again and began the open coding by a sentence-by-sentence examination of each text (naming fragments of the data and making marginal notes).

In a process of a sentence-by-sentence examination I constantly asked myself, "What is this about? What is the intended meaning of this text? What core beliefs does it imply? How does it respond to the research worldview questions?" I coded all textual units and some illustrations (pictures are not in the center of analysis, but some of them were found very benefiting for the study). In a process of analysis I constantly used all employed in the study methods. Each time a phenomenon of my interest appeared, I made a note in the margin. Codes emerged through constant comparison of information, when I noticed that they fit together. I grouped codes in broader categories, which I then compared with one another to make sure that they were mutually exclusive. This systematic act of coding continued throughout the research process. As the categories and themes were developed and coding was well under way, I made first attempts to interpret what I had learned about and summarize key points of findings. At the same time I was constantly scrutinizing the data as well as my interpretations to see where I might have applied my own biases or distorted the facts, whether my interpretation was honest. While I continued the 
process, I was comparing the themes and interpretations, checking them against the data I had, to see whether I needed to collect more data. Thoughts, insights, surprising ideas I had developed were accurately reflected in the analytic memos. From time to time I reviewed the direction my analysis was taken me to see whether it fit or did not fit my premises. I constantly challenged my explanations looking for other plausible explanations, for other data, implicit relations, and alternative explanations. This continued until I was confident that the categories implicating response to basic worldview questions had been identified. In each category, I searched for information until I found that the category was saturated (Saumure \& Given, 2008). For determining saturation, I used the criteria such as the empirical limits of data, the integration and density of the theory, and my own theoretical sensibility. Given that I had deal with two sets of data, categories were developed for each set separately, and integrative explanations were developed around categories of each set. The interpretation crystallized the control beliefs undergirding the content of Bukwars under consideration. These control beliefs became indicators of worldviews. During the next stage of analysis I compared world views indicators revealed through the content of both sets of textbooks with those suggested by Dennis McCallum(1997) to see what world views these indicators fit. The results were juxtaposed and interpreted in the context of cultural and political transformations that had occurred in Ukrainian society.

To ensure credibility of data interpretation, I have used peer debriefing and intercoder reliability, and low inference descriptors. I had an opportunity to debrief my data analysis with one of my knowledgeable colleague. Her reactions to the coding, and memos, and interpretations were valuable. The questions she asked in a process of reviewing helped to discover some gaps in my explanations. Intercoder 
reliability ensured the consistency in meanings and applications. To have more accurate description of data, and to enhance the interpretative validity of research, I used low inference descriptors. I kept the inference descriptors as close as possible to the raw data. 


\section{Chapter 4: Results and Analysis}

\section{Introduction}

As discussed in Chapter 1, this research examines how the content of Soviet and contemporary Ukrainian Bukwars addresses basic worldview questions:

1. Metaphysics: Is reality essentially spiritual or material?

2. Philosophical anthropology: Are human beings inherently spiritual or material?

3. Axiology: What is valued?

4. The problem of evil: What is wrong?

5. Ethics: How should we then live? (Gruber \& Baumann, personal communication, July 11-15, 2011)

The results of the qualitative observations to the data are presented in the form of emerging themes.

\section{Description of the Data}

Contemporary Ukrainian Bukwars. Pryshchepa, K. S., \& Kolesnychenko, V.I. (2010). Bukwar; Vashulenko, M. S., \& Vashulenko, O.V. (2012). Bukwar. Metaphysics: Is reality essentially spiritual or material?

- There is God.

- There is fortune.

- There is much more than this sensible universe.

- Sense of existence: Why do I exist?

- Physical world interact with spiritual world.

- Nature is friendly. 
- Is it possible to know anything at all?

Philosophical Anthropology: Are human beings inherently spiritual or material?

- A person is more than a physical body.

- Human life has a price.

Problem of evil: What is the solution?

- No enemies no problem.

- Problem of evil: Enemies will vanish.

Axiology: What is valued?

- Family is valued

- Education is valued

- Reputation is valued

- Family - the basis of ethical authority

- End justifies the means

- Good workers are valued.

- Motherland is valued.

Soviet Bukwars. Skrypchenko, N. F., \& Vashulenko, N. S. (1985). Bukwar;

Horetskyi, V. G., Kiryushkyn, V. A. , \& Shanko, A. F. (1985).

Metaphysics: Is reality essentially spiritual or material?

- Lenin died, but Lenin is alive.

- Ultimate goal-triumph of Communism.

- Everyone is supposed to become a communist.

Philosophical Anthropology: Are human beings inherently spiritual or material?

- Human beings are in control. 
- Self-dependence of the man.

\section{Epistemology:}

- Lenin is a source of wisdom.

Axiology: What is valued?

- Lenin is valued.

- Lenin's creed is valued.

- Labor is valued.

- Party - the basis of ethical authority.

- Good workers are valued.

- Education is valued.

- Comradeship is valued.

- Good mothers are valued.

\section{Data Analysis}

Contemporary Ukrainian Bukwars. Pryshchepa, K. S., \& Kolesnychenko, V.I. (2010). Bukwar; Vashulenko, M. S., \& Vashulenko, O.V. (2012). Bukwar.

There is God. The very first thing a reader sees in Pryshchepa \& Kolesnychenko's (2010) Bukwar is a beautiful picture depicting four seasons in one painting, the boundless sky and rejoicing nature. Every season brings its fruit. The fields are ready to be harvested. Everything sings with joy and life. What is the next that we see? We see a prayer in a form of poem written by Katherina Perelisna; the text of the poem is printed over the picture. The prayer is to God (the word God is capitalized). In the poem little children ask God to give them happy, healthy and long life. 
Пошли нам , Боже, маленьким дітям, / щастя, здоров'я на довгі літа! / Щоб виростали розумні й сильні / Душею чисті і серцем вільні. / God, give us little children / happy, healthy and long life / In order they become clever and might, / have pure souls and free hearts. (Pryshchepa \& Kolesnychenko, covering)

There is an illustration to the poem. In the picture down on the earth under the prayer closer to the right corner, we find a Christmas tree with a big shining Christmas star. The Christmas star on a Christmas tree reminds us about Christ's birth and sends the Good news to us (Christmas is merry!) and points out what God the prayer is addressed to.

The poem sends the very first message to young readers. There is God, our life and its quality depends on Him. A human being is much more than just a physical body. Intellect, soul and heart all together with a physical body make him what he is. Such distinguishing is Biblical; it is growing out of a Biblical view on a man. The Bible English Standard Version (ESV) in Genesis 1:27 says, “And God created man in his own image, in the image of God created he him". The Bible commanding us to love God by what we think, who we are, what we do, and to make Him a center and source of our life, also affirms the view of a man as a unity of material and immaterial parts. "Love the Lord your God with all your heart and with all your soul and with all your strength and with all your mind" (Luke 10:27).

This poem is the very first thing the young readers will repeatedly see every time they open their Bukwar, and it gives a clear worldview message: This sensible universe is not all that there is. There is God who is distinct from the world. He rules over it, otherwise, a prayer to God would be simply an idle attempt. He transcends the world and is continually involved in its life, particularly life of a human race. People are created in His image, and they themselves, their present and 
future depend on Him. There is a material side of a man (physical body) and immaterial side (soul and spirit - faculties of mind, emotions, will, the inner being); both parts are unified. It is the perfection of immaterial faculties what is valued, the material well-being also serves this purpose; it is the point of the prayer.

In addition, the prayer itself presupposes the right position before God; to dare to address Him in prayer one must accept Him as the Lord, as the ultimate authority beyond time and space in all areas of life. Submitting himself under His authority presupposes acceptance His objective ethical standards and moral values.

Finally, the prayer itself is recognition of personal helplessness (request to give happy, healthy and long life). Without God a human being feels helpless, without God's help people are not happy, not content, get sick and die, however God has a solution for this problem.

The opening poem in Pryshchepa and Kolesnychenko's Bukwar, as it seems to me, is nothing but the worldview Credo, in a nutshell. It is interesting to see, whether the rest of content is in line with it.

There is another prayer to God within a spring song poem. It is a prayer to God to provide bountiful harvest:

Та вроди , Боже, житечко, / ще й озимую пшеницю і усякую пашницю. / Bring forth, God, wheat, / winter crops, and also any bread. (Pryshchepa \& Kolesnychenko, p. 147)

It should be noticed that many texts of Pryshchepa and Kolesnychenko's Bukwar somehow relate to the idea of bread. This demonstrates that historically and traditionally for Ukrainians good harvest used to signify bread on the table, well being and life. It suggests that praying to God for harvest is recognition of His 
ultimate authority over nature, and of the total dependence on Him of a human race. The prayer is interweaving with a spring song. The meaning of song is enforced by a picture of the budded willow bouquet, with painted Easter egg (pysanka) and cross, reminding us about Willow Sunday (last Sunday before Easter, when Jesus entered Jerusalem), His crucifixion, and glorious Easter day - Jesus' resurrection. The same motif is continued on the next page in a poem "Pysanka" (Pryshchepa \& Kolesnychenko, p. 148). Unfortunately, it should be recognized that Bukwar does not provide any explanations regarding who Christ is, and why people celebrate Christmas and Easter. Spiritual aspect of these holidays is lost behind religious symbols and traditional activities. So, actually, Bukwar leaves children with the idea that Christmas and Easter are religious holidays Ukrainians used to observe. Nevertheless, the main message is definite - there is God and the reality is much more than people can sense or comprehend.

It should be admitted that Vashulenko and Vashulenko's (2012) Bukwar gives space for ambiguity on this issue by saying that "a garden provided everyone with wonderful gifts" (p. 87). These words by themselves do not claim that the world has appeared in a process of evolution. But they do imply that many things we think of are merely natural occurrences, and nature itself, according to seasons, brings forth some fruit for man, and that God (if the very idea of His existence is not denied) may not be the One who rules over everything what exists. Yet the Bible teaches that God causes even the grass to grow, "You cause the grass to grow for the cattle, and plants for man to cultivate, that he may bring food from the earth" (Ps. 104:14). In Ephesians 1:11 we find that God "accomplishes all things according to the council of his will"; it means that nothing falls outside of his providence. 
Nature is friendly. There is another aspect, I believe, that the above passage from Bukwar implies. By presenting the nature as something friendly, it rejects the consequences of the Fall and presents the fallen world in the way as the world should be. The disintegrated reality is presented as integrity hiding its true sinful nature.

There is fortune. The idea of fortune evokes the feeling that there is something much greater than this material world, something that is the master of human fate that influences human lives. According to The Dictionary of Symbols of Ukrainian Culture, concept fate represents God as the Highest Power; happiness and luck; at the same time it represents misfortune; woe; calamity; need; poverty; inevitability (2002, p. 79). Historically, Ukrainians interpret it as a combination of circumstances which either makes your life easier or harder. Such interpretation goes along with belief that each person or even a nation is a creator of own fate. Moreover, for Ukrainians, concepts of fate and freedom are inseparable: no freedom, no good fate (Sharmanova, 2009). This shows why lacking freedom means lacking all, and explains the desire to get freedom at all costs.

It's worth noting here that through the content of both contemporary Ukrainian Bukwars the idea of fate is reinforced. In a New Year poem the author identifies it with luck and happiness, favorable for a person's combination of circumstances, and something that is out of human control. In the other text, however, we find that it can be fought against by a person; and it can be changed. A life story of the famous Ukrainian writer Lesia Ukrainka who had an incurable disease (tuberculosis of the bones) teaches young readers that "contrary to evil destiny" (Pryshchepa \& Kolesnychenko, p. 160) she had managed to be become a famous writer. 
Sense of existence: Why do I exist? The idea of fortune invokes ontological questions of epistemological order. In his poem “The Poplar" (1839), Taras Shevchenko - a famous Ukrainian poet and writer - describes the unhappiness and tragedy of doomed love. A fortuneless young woman has become a poplar. It stands beside the high-road and the wind fells her to the ground. "Why has she a slim, tall trunk? Why are her broad leaves green?" Through legend Shevchenko brings up the issues of social character by intertwining the destiny of a young woman with the destiny of a whole nation. However, if looked from a worldview standpoint, this nexus is also of metaphysical character. The destiny of a person is considered at in the light of the destiny of a nation, and even more in the context of a destiny of the world. Questions "Why has she a slim, tall trunk? Why are her broad leaves green?" invoke question, "Why do I live?"

Is it possible to know anything at all? Vashulenko and Vashulenko' Bukwar asks the reader, "Where is the clouds sweet home? Where are they running? (p. 99). If looked from a worldview standpoint, these questions of metaphysicalepistemological character. Although the Bukwar keeps silence on this matter, a skillful teacher may use these questions to lead their thoughts in a particular metaphysical-epistemological direction on the matter of the origin of the world, whether it is possible to know anything at all, and whether the truth is objective or subjective in essence.

There is much more than this sensible universe. The idea that there is much more than this sensible universe is also reinforced by introducing to students other concepts, such as paradise, angel, church, cross, and holiness. 
A concept of paradise is applied in Bukwar to describe the native land.

Readers should understand that their "native land is an earthly paradise" (Pryshchepa \& Kolesnychenko, p. 85). The word paradise is used with the meaning the best place. However, the concept of earthly paradise itself includes the concept of other, that is to say heavenly paradise, and consequently, the existence of the opposite - the hell. This concept evokes the idea of spiritual world inhabited by spiritual beings, rebellion of angels against God, the first Paradise on the Earth and the story of first people, the story of their fall, and how the Gospel comes in power to triumph over the dark force.

A concept of angel. Mother compares her good sons with angels. She says that her sons are her angels (Pryshchepa \& Kolesnychenko, p. 162). For her they are embodiment of the best and the lightest of what a human race can have. No one on the earth is like them. They are the help and protection.

A concept of church. The idea of importance of such an institution as church is reinforced by including the church temples into the general landscapes of Ukraine (Pryshchepa \& Kolesnychenko, pp.126-127; Vashulenko \& Vashulenko, pp. 67, 84, $116,119,129,142,149)$. It is an indication of the Ukrainian nation belonging to a Christian world. The church building itself is a powerful symbol. The actual building is a visible expression of God's abiding presence amongst us and in us. Church is the place for worship to God, and the history of Ukraine proves its tremendous role as the center of spirituality and enlightment. In illustration to the poem about Ukraine as our Motherland that follows the Ukrainian anthem in Vashulenko's Bukwar (p. 5), the boy and girl in national costumes hold Ukrainian 
flag. There is a beautiful Ukrainian landscape behind them, both urban and rural with the church temple towering over it.

A concept of monk. The idea of spiritual exploit is introduced through the concept of "monks". There are people who seem appreciate spiritual things more than earthly things.

A concept of cross. The poem "Hoivka" ("A Spring Song") is not only reminding us about Easter tradition to paint the eggs but what should be painted on the Easter egg. And the very first thing which is mentioned is a cross the deep symbolism of which hardly needs interpretation. It is the main symbol of the Christian religion; it recalls for us the Crucifixion of Jesus Christ. He was crucified but He resurrected and the cross reminds us about the redeeming power of His Passion and death.

A concept of holiness. Ukrainian singers used to sing on Christmas Eve tells readers that lambs are born in a barn that night (Pryshchepa \& Kolesnychenko, p. 146), reminding us about events of the night when Christ was born: when and where and why Christ was born. The author of Bukwar refers to Christmas Eve as a Holy night introducing a reader to the concept of holiness, which totally belong to the realm of Holy God. The only way for a mortal to obtain holiness is by faith and by accepting Jesus as the Lord and Savior, then God sets us apart from the world (1 Peter 2:9).

Physical world interact with spiritual world. As above analysis has shown, contemporary Ukrainian Burwars present spiritual world as a dimension of reality which is inseparable from this earthly life. People have access to it through prayer 
and have hope that God will respond and reveal His power in the material world. At the same time they may expect intrusion of fortune, and this makes them vulnerable. Although, they may influence it and change it, so there is hope to change for the better.

A person is more than a physical body. In line with the discussion we have started at the beginning of the chapter, Both contemporary Bukwars under consideration in "The National Anthem of Ukraine" (a poem written by Pavlo Chubynsky in 1862, the music composed by Mykhaylo Verbytsky in 1863) recognize that a human being is much more than just a physical body: "Souls and bodies we'll lay down, all for our freedom". As we can see, although the distinction between soul and body is preserved, human life becomes a relative value. The idea that the worth of man may depends on things of this material world. In other words, human life has a price which is defined by circumstances. To rule "in a free land of our own" - is the benefit the cost of which is human souls and bodies. The idea that human worth can be defined or measured by other human being undergirds a saying that "a man without Motherland is a nightingale without song" (Vashulenko \& Vashulenko, p. 128). It assumes is that a man without Motherland has less worth. This contradicts the Biblical view of a man and his worth as God's image bearer.

No enemies no problem: Enemies vanish. "The National Anthem of Ukraine" is the part content of both contemporary Ukrainian Bukwars. It considers the enemies of Ukraine to be the root of its miserable state. Total destruction of enemies at all costs is the solution of the problem. Interestingly, enemies of Ukraine are believed to disappear in a natural way; it means that fate will provide the help.

Ukraine has not yet perished, nor her glory, nor her freedom, 
Upon us, fellow Ukrainians, fate shall smile once more.

Our enemies will vanish like dew in the sun,

And we too shall rule, brothers, in a free land of our own.

(Chubynsky, 1862)

There are a few things to be stressed. First of all, that ethics grows from needs and situation. To rule "in a free land of our own" - is their benefit the cost of which is human souls and bodies. Furthermore, "enemies of Ukraine are believed to disappear in a natural way "like dew in the sun", that is that Fate will help. Such strong belief in a power of fortune seems very promising.

What is valued? The analysis reveals that the family is of the greatest value. The unity with the family is very important for a person. Family becomes the basis of ethical authority. What the person is taught is considered to be true knowledge. It is the family that defines what is good for a man. It is the family that teaches that education and reputation should be valued.

У сім'ї хлопчика привчали до праці, поваги до людей. I, звичайно ж хотіли, щоб дитина вчилася на радість батькам, на добро людям. / The family taught the boy to be a hard worker, to respect other people. They definitely wanted the child grow in favor of the family and other people (Vashulenko \& Vashulenko, p.144).

The story "The Sons" includes a number of percepts that lead readers to a particular portrait of a good man. According to it, a good man is the one who follows and obeys the following commands:

Guard your name.

Watch your life, listen to the wise, learn from others, and favor other people. Honor those who are older than you, do not offend those who are younger than you, keep your word, be free of debts, be thankful for good advice and deeds (Pryshchepa \& Kolesnychenko, p. 162).

In the end of the story we also find that good children and grandchildren happily take care of their parents, and then parents feel happy and young. The illustration shows 
three generations (grandparents, parents and children) sitting happily at the round table and having tea.

Almost all of these moral percepts find their confirmation in the Bible. In the Bible we find the following truth:

A good name is better than precious ointment, and the day of death than the day of birth. (Ecclesiastes, 7:1)

And Jesus kept increasing in wisdom and stature, and in favor with God and men. (Luke, 2:52)

Honor everyone. (1 Peter, 2:17)

Owe no one anything, except to love each other. (Romans, 13:8)

Honor your father and your mother that your days may be long in the land that the LORD your God is giving you. (Exodus, 20:12)

Your children will be like olive shoots around your table. (Psalm, 128:3)

Grandchildren are the crown of the aged, and the glory of children is their fathers. (Proverbs, 17:6)

However, the precept "to be thankful for good advice and deeds" is not in line with the Bible that teaches that we must express thankfulness for every event or person, or circumstance He brings in our life (Ephesians 5:20).

The idea of knowing the family roots (Не цурайтесь свого роду! / Remember your roots! (Vashulenko \& Vashulenko, p.114) seems to be important. The National anthem says that we are all brothers, through the text the image of Ukraine emerges as the mother of all Ukrainians. Pryshchepa \& Kolesnychenko's Bukwar encourages young readers to learn about their predecessors, they are given an example how to put together a family circle (a family tree). However, in the sample diagram all family members center around a child himself. "ME" (p. 154) towers in the center, which to my mind gives a child an ego-centric message.

Work ethics is important. Burwar teaches children to be industrious and to work hard. They also do not contradict the Bible. The Bible teaches us, "If anyone is not willing to work, let him not eat" (2 Thessalonians, 3:10). In the Bible we also 
find that "In all toil there is profit, but mere talk tends only to poverty" (Proverbs 14:23). However, the content develops also the idea that, if one works hard enough, he can achieve everything. Such position does not leave place for God, denies human weakness and limitation, and put all trust and hope in self.

Vasyl Symonenko's poem says, "You can choose anything, son, but your Motherland" (Vashulenko \& Vashulenko, p. 128). The direct point of a poem is that a person cannot decide where to be born. However, if to think of the idea that a person can choose anything in the worldview terms, we see that it maintains the idea of relativity and subjectivity of values. It maintains that a person has freedom to choose anything; what to believe in, consider good or bad is up to an individual (or to the family, as the above discussion suggests). The idea of leading principle implies that end justifies the means. Thus, it becomes obvious that Burwars teach some biblical principles, but the core of axiology is not Biblical.

In conclusion, it should be added that among the fairy tales of the contemporary Bukwars we find the tales teaching value of the family ("Repka"), obedience to parents ("Kolobok', "Volf and 7 Calfs"), develop courage and selfdiscipline, ("Cat and Cock"), teach to be a hard worker ("Volf and Man"), to be honest ("Painted Fox"), teach to treat other as you want to be treated yourself ("Fox and Crane").

The story Buratino deserves a separate discussion. Buratino (Ukrainian: Буратіно) is the main character of the book The Golden Key, or the Adventures of Buratino (1936) by Aleksey Nikolayevich Tolstoy. The story is based on the 1883 novel The Adventures of Pinocchio by Carlo Collodi. In the beginning of the story Buratino is ill-behaved wooden boy, lying even to his father. The whole story 
centers on the search for a golden key, which can unlock the door to magic world of universal happiness. Unlike Collodi's fairy tale, at the end of Tolstoy's tale, Buratino does not need to become human, for he already behaves like a Soviet citizen.

Balina, Goscilo, and Lipovetsky (2005) provide an exhaustive analysis of the story Buratino: In a socialist narrative Buratino is a product of a collective effort. It is not the magic power but a collective, friends that help him to unlock the desired door, at the same time bringing out the best in him as an individual. "In this respect The Golden Key resembles the most celebrated socialist realist Erziehungsroman (novel of education), Anton Makarenko's Road to Life (Pedagogicheskaia Poema, 1939). Makarenko shows the power of a collective work toward a common goal as a perfect tool for transformation of delinquents (besprizorniki) into New Soviet Man. Buratino, similarly, demonstrates like a simple piece of wood, without appropriate heritage, and, moreover, affiliated with thieves (Alice the Fox and Basilio the Cat) "may be changed through proper collective endeavor and the support of his peers" (p. 112). Thus, on the one hand, "Buratino" remains one of the children's favorite fairy tales, with beautiful characters and many teachable moments. On the other hand, it is ideologically biased; and teachers should be aware of this fact; they should think critically when they use Buratino's character as an example or discuss him with the students.

It is important to see that all religious symbols and images used in Bukwars, such as the cross (p. 147), church temples, willow Sunday (last Sunday before Easter, Jesus' enter to Jerusalem) (p. 147), Easter bread (p. 27), painted Easter eggs (pysanka) (pp. 147-148), candle (pp. 148-149) represent the state Orthodox church, 
and, actually determining a leading religion undergirding a value system which should shape a value system of growing generations.

Significantly, the Bukwars content promotes national idea and national Church. Everything there beginning with Ukrainian state symbols, word choice (truly Ukrainians), selected texts, and illustrations, and ending with pictures of animal characters wearing Ukrainian national costumes serve the purpose to form a state-building mentality of growing generations.

Soviet Burwars. The very first pages of Soviet Horetskyi, Kiryushkyn, and Shanko's (1985) Bukwar set the goal for the youngest, "You will learn how to write and to read, for the very first time in your life you will be able to write the most precious words for all of us: mother, Motherland, and Lenin. The school will help you to become a literate and diligently working citizen of our great Motherland - the Union of the Soviet Socialist Republics" (Horetskyi et al., covering). The rest of the textbook both content and illustrations faithfully support this goal. Pictures of Lenin, the Communist leader and the founder of the Soviet state, (his portrait) start and conclude (Lenin surrounded by children) the textbook setting for the students a role model they are expected to follow. The symbols of the Soviet Union (National anthem of the Soviet Union, the red flag, state emblem, five-pointed and filled red star, hammer and sickle, red color itself) through the text enforce the idea that the life of every person is indissolubly connected to the life of the country - the USSR. They work as cognitive orienteer constantly returning the students to the goal they must pursue. The red banner has the hammer and sickle overlapping each other symbolizing the unity of industrial proletariat and the peasantry, the red star over it, representing the rule of the Communist Party, Soviet power and authority. Finally, 
the red color itself is the color of communism its worth to be fighting for at all costs. The state emblem shows the hammer and sickle and the red star over a globe, and two wreaths of wheat covered by the USSR state motto (Workers of the World, Unite!) in the official languages of the Soviet republics. Interestingly enough that in his book Icebreaker, Victor Suvorov (1988/1990) points out that it is the emblem of the Soviet state that points out the USSR ultimate goal - extending Soviet power over the world. The five-pointed and filled red star pin with a portrait of Lenin as a child in the center(indication of membership at the Little Octobrists Organization), a pioneer tie - a red neck kerchief (the Pioneers, All-Union Lenin Pioneer Organization), the Komsomol Pin Badge the USSR flag with Lenin's Portrait on it (Komsomol, Russian abbreviation of Vsesoyuzny Leninsky Kommunistichesky Soyuz Molodyozhi, English All-Union Leninist Communist League of Youth), Communist party membership ticket (card) - indication of belonging to the Communist Party organizations for people of different age groups, and at the same time a right blueprint for a life for every Soviet person. The choice to live life differently turns the person in the outsider. Such person is not allowed to benefit from the Soviet system. In particular, believers refusing to join the Communist organization were deprived of their right to enter the institutions of higher education, unofficially, of course. In Soviet times to enter the institution of higher education the recommendation from the Komsomol organization was among the papers allowing a person to apply for the degree. Of course, the recommendation assumed active membership in the Komsomol organization.

Skrypchenko and Vashulenko's (1985) Bukwar follows almost the same order of things. We find in the beginning of the textbook, a picture of Lenin as a child holding a book in his hand. The caption preceding the picture tells pupils that Lenin 
himself also has begun his way of life from Bukwar; and points out the ideal rolemodel for every Soviet student without exception must follow. On the portrait, to which pupils have brought flowers, Lenin is thoughtfully looking into the distance, he smiles as if he is seeing the future and knows what the future is. Lenin's image is used as a symbol of wisdom and hope. The poem on one of the concluding pages saying, "Learn from wise Lenin how to live, love your great nation as Lenin did" (Skrypchenko, p. 103) enforces this idea. The hymn to Lenin is followed by glorification of a Soviet country uniting 15 nations, then by praise of labor in general, and labor of Soviet people of different nationalities in particular, and then by the benefits to individuals, and the power of the USSR on the earth and in the space. It should be stressed that a general glorification of the Soviet state bringing abundance and happiness for people is a prevailing topic of both Bukwars. This provides rich ground to discuss the ideological staff and the tool of propaganda used to indoctrinate the youngest population; nevertheless, as it may seem, the authors of the textbooks keep silence regarding the control beliefs undergirding the Soviet Bukwar content. However, it is this silence that speaks louder than words about the Soviet Bukwar worldview foundation.

Metaphysics. Burwar never mentions that there is God, but, as its message shows, pictures of Lenin have replaced Orthodox icons that could be found in every house before the BolsheviK revolution. His portraits are found on the walls of every official and unofficial mansion.

Він усміхається вам доброю усмішкою з портрета. Проводжає до школи і зустрічає там. Він радіє за ваше щасливе дитинство./ He is kindly smiling at you from his portrait. Seeing off and welcoming at school. He is glad of your happy childhood

В дитячій кімнаті, де сонце і сміх, з портрета всміхається Ленін до всіх. / There is a dear portrait in a children's room, the room filled with 
the sun and laugh, Lenin smiles at everyone. (Skrypchenko \& Vashulenko, p. 103)

The hidden message of the text is that Lenin is alive, though he died long ago. He is good; he is omnipresent and omnipotent. He is in a grave but still is alive. His party leads people to the Communist paradise. It is where Soviet people will end:

Партия Ленина - сила народная / Нас к торжеству коммунизма ведет! / О Party of Lenin, the strength of the people, / To Communism's triumph lead us on! (Horetskyi, Kiryushkyn \& Shanko, p. 127)

Epistemology. Lenin is a source of wisdom:

Учіться у мудрого Леніна жить, / народ свій як великий як Ленін любить. / Learn from wise Lenin how to live, / and love your great nation as Lenin did (Skrypchenko \& Vashulenko, p. 103)

What is good? The voice of the October child is decisive. The definition of good is constructed from human understanding.

Что такое хорошо и что такое плохо? Крошка-сын /к отцу пришел,/ и спросила кроха:/- Что такое хорошо/ и что такое плохо?/ Если ты/ порвал подряд/ книжицу и мячик,/ октябрята говорят:/ плоховатый мальчик./ Если мальчик/ любит труд/ тычет/ в книжку/ пальчик,/ про такого/ пишут тут:/ он/ хороший мальчик. / A little munchkin / came to his father /and asked: / 'What is /good / and what is / bad?'If you've torn up / a book / and then / a ball, / as the October children say: / 'Bad boy!'/ If a boy / loves hard work, / and pokes / his little finger / in a book, / let it be written / about him here: / He's / a good boy. (Horetskyi, Kiryushkyn \& Shanko, p. 120)

What is valued? Motherland and Lenin are as important as mother:

Ты научишься читать и писать, впервые напишешь самые дорогие и близкие слова: мама, Родина, Ленин./ You will learn how to write and to read, for the very first time in your life you will be able to write the most precious of all of our words: mother, Motherland, and Lenin. (Covering). Interestingly, as Bukwar says, "Good mothers are valued".

Good mothers are valued; and consequently respected and obeyed. What about bad mothers? What do they deserve?

Хай живуть хороші мами всіх дівчаток і хлоп'ят / Long live good moms of all girls and boys! (Skrypchenko \& Vashulenko, p. 98)

Lenin's portrait is valued: 
Дорогий портрет ... 3 портрета всміхається Ленін до всіх. / There is a dear portrait in a children's room ... Lenin smiles at everyone. (Skrypchenko \& Vashulenko, p. 103)

Lenin's creed is valuable and trustworthy. It is so good that all people of the USSR as one can be faithful to it:

Ми вірні справі Леніна! /We are faithful to Lenin's creed!”

(Skrypchenko \& Vashulenko, p. 49)

Academic excellence becomes a key factor of success:

Учись на отлично, каждый день занимайся зарядкой, закаляйся. И твоя мечта обязательно сбудется./ Be an excellent student, work out every day and have a healthy lifestyle; then your dream will come true" (Horetskyi, Kiryushkyn \& Shanko, p. 101).

Conscientious work is a way to make dreams come true. To be a good worker, indeed, does not imply to be a good person. However, it does imply selfdependence. In Skrypchenko \& Vashulenko's Bukwar we find

Землю прикрашає сонце, а людину - праця. / The sun adorns the earth, but labor adorns the man" (Skrypchenko \& Vashulenko, p.99).

You should not only dream, but You must work toward your dream.

Then your dream will come true (Skrypchenko \& Vashulenko, p. 150)

Such self dependence, along with tunnel thinking, and belief in scientism (a belief that science alone can render truth about the world) makes a Soviet individual believe that he is managing and ruling the nature. This idea has been implanted into young learners' heads and hearts. In "The Yellowbird" an ordinary Soviet girl Varia decides when it is time for the yellowbird to sing.

У Вари был чиж. Чиж жил в клетке и ни разу не пел. Варя пришла к чижу.

-Пора тебе, чиж, петь./ Varia had a yellowbird. It lived in a cage and it had never sung. Varia came up to the yellowbird, "It is time for you to sing." (Horetskyi, Kiryushkyn \& Shanko, p. 96). 
In addition, there is unwritten duty to sacrifice personal pleasure and happiness, to pleasure and happiness of others; and prefer the country or your comrade's interest to your own. It seems that it is not imposed. For instance, in a story about Fedia and Igor, the question "how to act?" is left without response:

Однажды были лыжные соревнования. Федя и Игорь бежали рядом. Уже совсем близок финиш. Вдруг Игорь упал и у него сломалась лыжа ... Как бы вы поступили на месте Феди? / Once there was a competition. Fedia was running next to Igor. The finish is very close. All of a sudden Igor has fallen down. His ski has broken. If you were Fedia, what would you do in such situation? (Horetskyi, Kiryushkyn, \& Shanko, p.112)

Each young reader has a freedom to answer individually, according to personal understanding; but, the teacher in a classroom definitely will make sure that each response and a way of thinking is correct and does not contradict Communist ideals. It is expected, as the popular saying goes, to die for a friend. The idea of comradeship as well as the idea of sacrificial love should not be something extraordinary for a Soviet man; it is expected to be a part of a daily routine. This is the message that young readers should absorb unconsciously from the pages of Bukwar. Yet, such principle of sacrificial life is not in line with a human and egocentric message of Skrypchenko and Vashulenko's Bukwar text "May there always be sunshine", the final line of which proclaims, "May there always be I!" (p.105).

Interestingly, one Biblical percept has remained on the pages of Soviet Bukwar. As you sow so shall you reap (Horetskyi, Kiryushkyn \& Shanko, p. 118).

Among other percepts in Bukwar many teach to love the labor and encourage individuals to get high achievements in work. Honest labor is praised, it is among the best values of the Soviet Union; it is adornment of any person. Everyone is 
expected to want to be a good citizen; therefore, they must be diligent in all spheres of life and work hard.

Будь старательным и трудолюбивым!/ Be diligent and work hard! (Covering).

Труд кормит, а лень портит. \Labour feeds but laziness harms (p. 86).

Слава честному труду! / Glory to honest labor! (p.100)

The youngest generation was expected to grow learning how to obey the

Communist party instructions and completely trusting Communist leaders.

Horetskyi, Kiryushkyn and Shanko's Bukwar ends with images of Lenin and representatives of fifteen Soviet republics. In the picture Lenin has a friendly conversation with children. The picture is supplied with the words of Lenin's wife, the Minister of Education Nadiya Krupska. To remind young learners that Lenin wanted each of them to grow to become a communist, she asks every young learner Lenin's question, "You will become a Communist, won't you?" Thus, the Bukwar content gets its logical and expected product. Everyone is expected to give a positive response to this direct question. School in its turn can consider its goal be accomplished. The goal which is given at the very beginning of the textbook:

The school will help you to become literate and diligently working citizen of our great Motherland - the Union of the Soviet Socialist Republics" (Horetskyi, Kiryushkyn \& Shanko, Covering).

Conclusions. As analysis of Soviet Bukwars has shown, although Lenin is attributed by supernatural characteristics, there is no massage about belief in the existence of God. There is no a single line of the text telling about the existence of soul. Truth is considered to be subjective. Lenin is the only one who is perfect in knowledge and wise. There are no objective values or morals exist. Values are imposed from outside, and constructed from human understanding. Everyone is faithful to Lenin's creed. It implies that everybody trusts that what Lenin and the 
party say is the best future for everyone. Taking in consideration the goal of school, it was expected that starting from the elementary school, Soviet pupils would follow the CPSU instructions without any questions, live up to Communist ideals, and put into action directions of the Communist Party organized by great Lenin.

According to the design of the present research study I have compared world views indicators revealed through the content of Soviet Bukwar with those suggested by Dennis McCallum (1997) to see what world views these indicators fit. I came to conclusion that the Soviet Bukwar content is based on atheistic worldview.

As further analysis has shown, contemporary Ukrainian Bukwar has moved from a purely atheistic foundation (be honest, to my big surprise!) However, there is no coherency in a worldview vision undergirding its content. On the one hand, throughout the texts God is recognized as an ultimate authority, the Source and Holder of life; on the other hand a man preserves the right to decide what is good for him and defines the way how to deal with the evil. There is no clear concept of God, who is $\mathrm{He}$ and what His characteristics are. Christ reality is recognized and celebrated; however, He is not worshiped as God. In addition, the belief in fortune is alive and strong, that confuses even more the conception of spiritual reality, as spiritual dimension is identified with both God and the power of fortune.

Are human beings inherently spiritual or material? On the one hand, a man is understood as not purely physical being, even we may say inherently spiritual; on the other hand, there is no understanding that human worth comes from God who bestows that worth. That is why human life worth not much, and can be taken. 
There isn't one ethical or epistemological authority. Truth and values are constructed from human understanding. There is God but, there is no massage about objectivity of truth and reality of values, that "the value of anything else is derived from its relation to the reflection of God" (Gruber \& Baumann, 2011, personal communication).

Such ambiguity explains relativity of values and knowledge, and ambiguity of the Bukwar massage. We want our children grow and ultimately act according to Biblical percepts, but we also believe that people are creator sand masters of their own destiny (which is to some degree true). We want youngsters to pray and to observe Christian traditions, and follow Biblical percepts, and at the same time, we still remain our human "I - idol" on its pedestal, and centers our lives on it.

As further analysis has demonstrated, some texts of Contemporary Ukrainian Bukwars are grounded in control beliefs typical for a secular humanism that is an atheistic worldview, while other are rooted in Christian control beliefs. Regardless of the fact that the content rich in Christian concepts and religious symbols, the story of the world it creates remains unbiblical.

Thus, the findings reflect a strong tendency toward replacement of atheistic worldview foundation for the theistic worldview (Christian Theism). To maintain this process, and to accomplish it successfully, the content of the contemporary Ukrainian Bukwars should be reconsidered from standpoint of worldview coherency; otherwise it is likely to bring much confusion into heads and practices of growing generations. 


\section{Chapter 5: Discussion and Implications}

\section{Introduction}

The present study had as its main objective the analysis of elementary school literacy textbooks Bukwar used in public schools of Ukraine today and Bukwars that were printed on the eve of Perestroyka (1985) in Soviet Ukraine. The purpose is to see what a worldview undergirds their content, and define whether, if at all, contemporary Ukrainian Bukwar has moved from the Soviet control beliefs, whether it promotes and stimulates the formation of a new conceptual vision of the world, necessary for building democratic society. How the conceptual model of the world constructed within the contemporary Bukwar is different from the one taught twenty years ago during the Soviet Union times.

\section{Interpretation of the Results}

The analysis was designed to identify the position of contemporary Ukrainian Bukwars on the basic worldview questions (different positions result in different control beliefs, and consequently, different worldviews). To analyze the content of a selected set of Bukwars, I used a paradigm of several qualitative methods.

The findings reveal that contemporary Bukwar definitely has moved from totally atheistic foundation towards theistic worldview (Christian Theism). However, findings also indicate that there is no coherency in a worldview base undergirding Bukwar's content.

As it was discussed and detailed in Chapter 2, there is interdependence between the Bukwar content and the worldview that constitutes the hidden layer of the culture. In even more general terms, we may say that it is a dynamic interdependence and solidarity between the Bukwar mode of discourse and deepest 
layer of culture (cultural worldview foundation). On the one side, the worldview undergirding a particular culture shapes the discourses of this culture, constitutes their worldview foundation and reveals itself through them. On the other side, the capacity of discourse to embody worldview, to articulate the worldview it incorporates, and to produce particular human resource, in tandem with the factors providing for the implementation of a proper worldview turn the Bukwar content in a very powerful instrument of impacting the worldview foundation of individuals. Since, as discussed in Chapter 2, a replacement of a worldview foundation of any society is a matter of replacement of control beliefs of individuals of the society, by saying that Bukwar is a very powerful instrument of impacting the worldview foundation of individuals we mean that Bukwar is a very powerful instrument of impacting the worldview foundation of society. That is why, what is included in, or excluded from the Bukwar content is strategically important.

The findings in this research project indicate that in a worldview foundation undergirding the content of the accounting textbook incorporates both the control beliefs typical for a secular humanism and the control beliefs typical for theistic worldview (Christian Theism). Bukwar teaches to pray to God, but there is no clear message about who God is. It also never mentions that each man is His image bearer that can be distorted but never lost completely. This uncertainty is intensified by a presence of supernatural fortune that also, according to the Bukwar content may intrude into people's life, and change its direction according its will. This generates a vague idea about who is God and who is man; therefore, the idea that human life has a relative worth, and can be taken, if needed. 
Furthermore, the accounting textbooks teach children to be diligent students, to study and master professions, but it doesn't tell them that truth is objective, that it is only through God that we receive the proper understanding of life and reality.

In addition, contemporary Ukrainian Bukwar teaches children the Biblical percepts and expect them to act Biblically, but it does not teach them that God is the final standard of good. "No one is good but God alone" (Luke, 18:19). Good means "worthy of approval". "Because we are mere creatures, we are not free to decide by ourselves what is worthy of approval and what is not. What is good cannot be constructed from human understanding; value comes from relation to the absolute value of God, otherwise, they do not have value. There is no clear massage about this; moreover, there is a totally opposite message regarding this truth.

\section{Potential Application of the Findings}

As textbook problem in Ukraine has not been solved yet, scholars continue to work towards designing the textbooks which should meet the current educational needs. As the competency-oriented approach is being implemented, the revising of content of existing textbooks as well as developing the proper textbook content remains one of the key goals of Ukrainian education. The findings of the present research study contribute in this process by demonstrating that in-depth analysis of the worldview base should become a part of this revising-creative process. Moreover, they provide a compelling argument for the reconsideration of the content of contemporary Ukrainian Bukwars used to teach elementary school students all over Ukraine.

The teachers of the Basics of Christian Ethics and Christian Ethics in Ukrainian Culture school courses that are currently taught in many schools of Ukraine will benefit from the findings of the present research study too. The courses 
they teach are believed to be strengthening the spiritual health of the nation. The findings of the present research study rise awareness of educators teaching these courses about the factors leading to spiritual confusion of students.

In addition, findings of the present research study not only inform about the worldview shift that Ukrainian nation has been undergoing since the collapse of the USSR, but also point out at the role of school textbook discourse in this process; and the capacity of the Bukwar discourse to impact this process.

\section{Biblical Integrative Component and Implications}

Contemporary Bukwar says nothing about how evil entered the world; it keeps silence on consequences of the Fall. This contributes to formation of a disintegrated view of the world, world without God. A fallen world means disintegration. In a fallen world fallen human beings attempt to remain sovereign from God by developing their own normative visions of the world; and thereby developing the alternative worldviews.

Unlike the disintegrated view of reality, the integrated view of reality is a whole view. Integration requires understanding God and God's design for His creation. It is half of the truth to know that God is. Students should know that God is infinite and $\mathrm{He}$ is personal; Christmas is not merry only because it is a beautiful holiday, but because we celebrate incarnation of God; it is merry, because human race was given Good news. God is not somewhere there, but He is near through the Holy Spirit. The message should be that God is three Persons, yet one God, and there is no place for any fortune in this message.

God has created the man; and man always remains His image bearer. God wants the man to be a good steward and to develop the earth, to be a channel of God's blessing, to "multiply and to fill the earth" (Genesis, 1:28). According to 
Baumann (2010), students should receive the massage that God expects them to apply their "talents, abilities, knowledge, and resources for service to God by ministering to the spiritual, mental, emotional, social, and physical needs of other" (p. 23). God expects men to be the ministers of His ministry of reconciliation, to look for the ways of restoring the affected by sin areas to the authority of God, and returning to them God's beauty.

God is a standard of good and a source of morality. He has revealed His law to us and has spoken it to us through Ten Commandments. Truth is an objective category. He is absolute good, truth, and wisdom.

He has created this finite, material world. Reality is both material and spiritual. "The universe as we know it had a beginning and will have an end" (McCallum, 1997).

A half-truth does not bring spiritual healing, but does bring confusion. To be confused about such basic and ultimate issues is not healthy. People thinking that it is a normal situation for a transition period are drastically mistaken. Today's young people, most of them born after 1991, are the first generation to grow up after declaration of independence of the Ukrainian state. The lack of orderliness of their minds and consequently an inability to tell good from evil can be to some degree explained by the fact that their basic beliefs about reality were forming in the initial period of the worldview shift, when the old regime had collapsed and the future was still uncertain. However, it would be a mistake to expect from today's generation to be different, if the ultimate truth about reality they absorb remains not coherent.

\section{Relation of the Results to Theory and Other Literature}

As our investigation shows, once again Ukrainian society has been going through a worldview shift, has been moving toward theistic worldview - Christian 
Theism. Actually, in a span of 1600 years our nation has survived through three worldview shifts. I have already mentioned two of them. The very first one is identified with Christianization of Kievan Rus; the second one is identified with the Bolsheviks coming to power and establishing the atheistic society. Finally, the third worldview shift is still in a process. In its initial stage we identify with the collapse of the USSR and gaining by Ukrainians independence Time will show what an outcome of this process is. A collapse of the Party's absolute power and collapse of the Soviet Union has shaken the worldview foundation of Ukrainian culture once again. The iron curtain fell down, Ukrainian catacomb church came up from the under-ground; Ukraine received its first Apostles of faith - missionaries from Europe and America who brought the Bible. Reading the Bible by masses and hearing the Word of God questioned existing positions on the metaphysical-epistemological questions and demanded the critical revision of what individuals viewed as their authentic commitment. Every canon of the Marxist-Leninist theory of the state and the law was undermined inducing a worldview crisis, and inviting the replacement of the Soviet worldview control beliefs.

Since declaration of independence of the Ukrainian state, Ukrainian education has been searching for ways of consolidation of the Ukrainian nation; regeneration of truly Ukrainian educational tradition; and returning to traditional educational ideal. Much has already been done in this area, but much has remained the same. On the one hand, Ukrainians have benefited enormously from democratic reforms, religious freedoms, informational and experience exchange with foreign countries. On the other hand, in Ukraine old and new political powers have been constantly in interplay creating never ending political crises, causing political instability and making Ukrainians sink into misery and poverty. 
As the present study has shown, everything we observe on a surface of the culture is shaped by the hidden layer of the culture. Spiritual and physical misery of the nation should be explained by absence of a firm and strong worldview foundation. The fact that many people simply do not know how to live should be explained that they have a wrong conception of truth and reality. This wrong conception determines their value systems, defines the mode of thinking, and finds reflection in their behavior and practices. Not knowing true moral laws, having wrong concept of good, and not knowing a real root of evil, they fight against wrong enemies, make wrong choices, and then live the rest of life suffering from the consequences. Having no hope in the future, many people simply leave the country for better place to live. They do not understand that there they may find the same poverty and misery, because the problem is not in a place where they live, but in sin that separates them from their Creator in whose image they are created. They are lost, because they do not know that all truth is grounded in God and that, as Miller (1998/2001) points out, "All the "pieces" fit together in a coherent pattern to serve God's unfolding kingdom" (p. 104). It is true both for an individual and for the whole nation. Significantly, in order to see that Ukraine has finally changed for the better, the time must not be missed, and the desired outcome of the worldview shift that has been in progress since the declaration of its independence must be ensured; and the role of school textbook discourse in this process, especially what Bukwar teaches should not be overlooked.

There other important factors that should be considered in this context. Teacher's impact of learning process is the very first among them. The Article 35 of the Ukrainian Constitution declares that "the church and religious organizations in Ukraine are separated from the state, and the school - from the Church". However, 
it allows both believing and unbelieving teachers to teach at public schools.

Teachers who exercises a unique primacy over the text always implement and integrate elements of their conceptualization into their teaching. It is done by word, by action, or by attitudes. By doing so, the teacher may challenge and re-shape the students' worldviews and the worldview foundation of the school textbooks discourse. Thus, teacher' metaphysical-epistemological position also define whether the students will receive an integrated and comprehensive view of reality. This turns teacher in a key factor of educational process and shows that Ukrainian schools desperately need more teachers who is going to teach students "heart-to-heart" (Gruber, personal communication, July 11-15, 2011).

The role of the family in a formation of children's worldview should not be neglected. It used to be the powerful worldview formative agent. However, since independence, Ukrainian families have suffered from industrial, economic and moral decline, and many of them cannot provide a secure and stable home. Such situation makes children to look for answers to important for them questions elsewhere.

Finally, since Bukwar is the first textbook for the youngest students, it cannot give responses to all worldview questions. However, the matter is not in giving all, but in a coherence of what is given. Bukwar is not the only tool to form the worldview. It is only a piece in a worldview jigsaw; however, a key factor is that, if the vision of reality that Bukwar provides is distorted, the process of putting all pieces together will be detained and the final vision of reality will suffer very much.

\section{Strength of the study}

This is the first study, to our knowledge, to examine the worldview foundation undergirding the content of Soviet and contemporary Ukrainian ABC Bukwar textbooks. While some previous studies had scrutinized the content of 
Ukrainian History textbooks, to see the change of historical narrations since independence, the question how the content of contemporary Ukrainian textbooks addressed basic worldview questions remained unexplored.

A second strength of this research study is that the sample included 2 of 3 Bukwars that were recommended by the Ministry of Education and Science of Ukraine for use in a current academic year.

A third strength of this research study is my personal experience. I have been involved in the ministry focused on teaching Christian educators working in public schools of Ukraine how to teach their disciplines from Biblical perspectives. Taken in consideration that curriculum presents disintegrated picture of reality, the content of every lesson should be reconsidered and integrated with Biblical truth. Cooling and Green (2008) note that even "on the surface, math might seem as neutral subject as could possible exist - until you consider the prevailing worldview behind the kind of situations used as illustrations for calculations" (p. 15). The story every lesson presents should be transformed into a God's story.

It should be added in this context that, as I have already mentioned in Chapter 1, I witnessed myself the time of Perestroyka, the USSR collapse, and the events that led to Ukraine's independence, the Orange Revolution, and all dramatic postrevolution events. Such experience allows me to have an integrated understanding of events taking place in Ukraine.

A forth strength of this research study. To achieve greater understanding in this investigation, I have examined a full literature review of the topic of interest. In Kyiv, Ukraine I used sources from Dragomanov National Pedagogical University Library (a major higher education establishment preparing teaching personnel) and 
the Vernadsky National Library of Ukraine (one of the largest library in the country). I searched for all available research from online databases.

Finally, being a non-native speaker, for ensuring the validity of the interpretations of texts, I used a native peer-reviewer. The language and interpretations is also double checked by a native English speaking colleague.

\section{Limitations of the study}

The sample used for this research study does not include Bukwars used at schools for children who are not ethnic Ukrainians, such as the Roma, Crimean Tatars, Moldovans, Hungarians, Russians, and others (over 130 ethnicities). Russians are more concentrated in eastern and southern areas of Ukraine; this situation explains why the Russian language dominates and is preferable at schools there. Since recently the Russian language has received official regional status in Ukraine; it meant an official employment of Bukwars teaching how to read in Russian (which also were not the part of this research study).

This research study included juxtaposition of Soviet and contemporary Ukrainian Bukwars, but not juxtaposition of contemporary Ukrainian Bukwars, although each of them should present a picture of the world differently.

I also did not have chance to rely much on additional researchers for analysis, so it remains to be a threat to validity of this research too.

To some degree my personal worldview creates additional threat for a validity of this research. Although I have tried to control it by constantly looking for alternatives and trying to standardize the procedure of collection the data, I, as any other person, could not look outside my worldview lens.

\section{Suggestions for future research}


It remains to be seen whether the analysis of the worldview foundation of other textbooks used in public schools of Ukraine will yield the same results. In fact, future researchers may conduct the analysis of the worldview foundation of other textbooks used in public schools of Ukraine. What is even more exciting, future researchers may conduct a comparison of the newly published Bukwars with the older editions to reveal the conceptual lens accounting textbooks provide, to see whether the control beliefs they incorporate have become more coherent. As I have already mention the juxtaposition of contemporary Ukrainian Bukwars remains interesting issue for exploration. It is critical that educators continue to examine the contents of textbooks used in the classroom to see what ultimate aims they serve. What the world of the future will be like considerably depends on what control beliefs absorb those who are just learning to read now. 


\section{References}

Andrushchenko, V.P. (Ed.). (2003). Reform strategy for education in Ukraine. Kyiv, Ukraine: K.I.S.

Apple, M.W. (1992). The text and cultural politics. Educational Researcher, 21(7), 4-19.

Balina, M., Goscilo, H., \& Lipovetsky, M. (2005). Politicizing magic: An anthology of Russian and Soviet fairy tales. Evanston, IL: Northwestern University Press.

Baumann, E. K. (2008-2009). The Essentials of integration: The principle of reconciliation. CSE, 12 (2), 22-24.

Bishop, H., \& Jaworski, A. (2003). 'We beat 'em': Nationalism and the hegemony of homogeneity in the British press reportage of Germany versus England during Euro 2000. Discourse Society, 14(3), 243-271.

Boldyryev, N.N. (2001). Cognitive semantics: A course of lectures in English philology. Tambov, Russia: Tambow University Publishing./ Болдырев, Н. Н. (2001). Когнитивная семантика: Курс лекций по английской филологии. Тамбов: Изд-во Тамбовского университета.

Boychenko, T. (2011, January 21). Believers cleanse souls at Epiphany. The Kyiv Post, p. 25.

Candlin, C. N. (1997). General editor's introduction. In B-L. Gunnarsson \& B. Nordberg (Eds), The construction of professional discourse (pp. ix-xiv). London, England: Longman. 
Charmaz, K. (2006). Constructing grounded theory: A production guide through qualitative analysis. London, England: Sage.

Cooling, T., \& Greene, M. (2008). Supporting Christians in education. London, England: LICC.

Croft, W. (2009). Toward a social cognitive linguistics. In V. Evans \& S. Pourcel (Eds.), New Directions in Cognitive Linguistics (pp. 395-420). Amsterdam, the Netherlands: John Benjamins.

Croft, W., \& Cruse, D. A. (2004). Cambridge textbooks in linguistics. Cambridge, UK: Cambridge University Press.

Dijuk, T. A. (1993). Principles of critical discourse analysis. Discourse and Society, 4(2), 249-283.

Dobrovol'skij, D. (2011). The structure of metaphor and idiom semantics (a cognitive approach). In S. Handl \& H.-J. Schmid (Eds.), Windows to the mind. Metaphor, metonymy and conceptual blending (pp. 41-62). Berlin; New York, NY: De Gruyter Mouton.

Dooyeweerd, H. (1955-1958). A new critique of theoretical thought (4vols.). Philadelphia, PA: Presbyterian and Reformed Publishing Co.

Evans, V., \& Green, M. (2006). Cognitive linguistics: An introduction. Edinburgh, Scotland: Edinburgh University Press.

Fairclough, N. (1992). Discourse and social change. Cambridge, UK: Polity Press. Fairclough, N. (2003). Analysis discourse: Textual analysis for social research. London, England: Routledge. 
Fauconnier, G., \& Turner, M. (1996). Blending as a central process of grammar. In A. E. Goldberg (Ed.), Conceptual structure, discourse, and language (pp. 113-130). Stanford, CA: CSLI Publications.

Fauconnier, G., \& Turner, M. (1998). Principles of conceptual integration. In J.-P. König (Ed.), Discourse and cognition (pp. 269-283). Stanford, CA: CSLI Publications.

Fauconnier, G., \& Turner, M. (2002). The way we think. Conceptual blending and the mind's hidden complexities. New York, NY: Basic Books.

Ferraro, G. (2006). Cultural anthropology: An applied perceptive (6th ed.). Belmont, CA: Thomson Wadsworth.

FitzGerald, F. (1979). America revised: History schoolbooks in the twentieth century. New York, NY: Vintage Press.

Foucault, M. (1972). The archaeology of knowledge (3th ed.). New Yourk, NY: Routledge Classic. (Original work published in 1969)

Freiré, P., \& Macedo, D. (1987). Literacy: Reading the word and the world. London, England: Routledge.

Freire, P. (1972). Pedagogy of the oppressed. London, England: Penguin.

Gee, J. P. (2011). An introduction to discourse analysis. Theory and method (3th ed.). New York, NY: Routledge.

Geertz, C. (1973). The interpretation of cultures. New York, NY: Basic Books, Inc.

Hiebert, P. G. (2008). Transforming worldviews: An anthropological understanding of how people change. Grand Rapids, MI: Baker Academic. 
Hoeble, E. A. (1972). Anthropology: The study of man (4th ed.). New York. NY: Mcgraw Hill Publishing Company.

Hosking, G. A. (1993). The first socialist society: A history of the Soviet Union from within (2nd enl. ed.). Cambridge, Mass.: Harvard University Press.

Janmaat, J.G. (2002). Identity construction and education: The history of Ukraine in Soviet and post-Soviet schoolbooks. In T. Kuzio \& P. D'Anieri (Eds.), Dilemmas of state-led nation building in Ukraine (pp 171-190). London, England: Praeger.

Janmaat, J. (2007). The ethnic 'other' in Ukrainian history textbooks: The case of Russia and the Russians. Compare, 37(3), 307-324.

Johnsen, E. B. (1997). In the kaleidoscope. Textbook theory and textbook research. In S. Selander (Ed.), Textbooks and educational media: Collected papers 1991-1995 (pp.25-44). Stockholm: The International Association for Research on Textbooks and Educational Media (IARTEM).

Jaworski, A., \& Coupland, N. (1999). Introduction: Perspectives on discourse analysis. In A. Jaworski \& N. Coupland (Eds.), The discourse reader (pp. 144). London, England: Routledge.

Kaplan, V. (2005). History teaching in post-Soviet Russia: Coping with antithetical traditions. In B. Eklof, L. Holmes, \& V. Kaplan (Eds.), Educational reform in post-Soviet Russia: Legacies and prospects, (pp. 247-271), London, England: Routledge.

Kaplan, V. (2007). The history of reform in Russian higher education. European Education, 39(2), 37-59. 
Kinloch, G. C. (1981). Ideology and contemporary sociological theory. Englewood Cliffs, N.J.: Prentice-Hall.

Klein, E. (1969). Base. In A comprehensive etymological dictionary of the English language (Vol. 1, p. 151). New York, N.Y.: Elservier Publishing company.

Klein, E. (1969). Faith. In A comprehensive etymological dictionary of the English language (Vol. 1, p. 161). New York, N.Y.: Elservier Publishing company.

Knight, G. R. (2008). Issues and alternatives in educational philosophy (4th ed.). Berrien Springs, MI: Andrews University Press.

Kornard Koerner, E.F. (2000). Towards a 'full pedigree' of the 'Sapir-Whorf hypothesis': From Locke to Lucy. In: M. Pütz \& M. Verspoor (Eds.), Explorations in linguistic relativity (pp. 1-24). Amsterdam, the Netherlands: John Benjamins Publishing Co.

Kraft, C. H. (1996). Anthropology for Christian witness. Maryknoll, NY: Orbis Books.

Kraft, C. H. (2005). Christianity in culture: A study in dynamic Biblical theologizing in cross-cultural perspective. Maryknol, NY: Orbis Books.

Kumar. K. (2003). Ideology and political system. New Delhi, India: Discovery Publishing House.

Kuyper, A. (1999). The lectures on Culvinism. Grand Rapids, MI: WM. B. Eerdmans Publishing Company. (Original work published in 1931)

Kuzio, T. (2011, January, 21). Kuzio: Is Ukraine forever doomed to such a divisive political fate? Kyiv Post, p. 15. 
Kuzio, T. (2011). Political culture and democracy: Ukraine as an immobile state. East European Politics and Societies, 25(1), 88-113.

Lieven, A. (1994). The Baltic revolution : Estonia, Latvia, Lithuania and the path to independence. New Heaven, Conn.:Yale University Press.

Lickona, T. (2004). Character matters. New York, NY: Simon \& Schuster.

Lakoff, G. (1987). Women, fire and dangerous things: What categories reveal about the mind. Chicago, IL: The University of Chicago Press.

Lakoff G., \& Johnson, M. (2003). Metaphors we live by. Chicago, IL: The University of Chicago Press.

Langacker, R. W. (1991). Concept, image, and symbol. Berlin, Germany: Mouton de Gruyter.

Langacker, R. W. (1999). Grammar and conceptualization. Berlin, Germany: Mouton de Gruyter.

Langacker, R. W. (2001). Discourse in Cognitive Grammar. Cognitive Linguistics, 12(2), 143-188.

Luke, C., De Castell, S., \& Luke, A. (1983), Curriculum Inquiry,13(2), 111-127.

Luzbetak, L. J. (2000). The church and cultures: New perspectives in missiological anthropology. New York, NY: Orbis Books.

Luzbetak, L. J. (2000). The church cultures: New perspectives in missiological anthropology. Maryknoll, NY: Orbis Books.

McCallum, D. (1997). Christianity: The faith that makes sense (4th ed.). Wheaton, IL: Tyndale House.

Makarevych, H., \& Bezrohov, V. (2005). Construction of educational ideal in textbook. Development of Personality, 4, 79-99./ Макаревич, Г. \& Безрогов, 
В. (2005). Конструирование образовательного идеала в учебнике. Развитие личности, 4, 79-99.

Miller, D. L., \& Guthrie, C. S. (2001). Discipling nations: The power of truth to transform cultures (2nd ed.). Seattle, WA: YWAM Publishing.

Mills, S. (2004). Discourse (New critical idiom ) (2nd ed.). New York, NY:

Routledge.

Ministry of Economy of Ukraine. (2005). Ukraine: The millennium development goals 2000+5. Kyiv, Ukraine: 'Dija” Publishing House.

Mulenga, K. C. (2011). Changing risky behaviour through worldview

transformation: A pastoral intervention to the spread of HIV/AIDS in Zambia. $\mathrm{PhD}$ dissertation, University of Pretoria, Pretoria. Retrieved from

http://upetd.up.ac.za/thesis/available/etd-05182011-142851/

Nash, R. H. (1992). Worldviews in conflict. Grand Rapids, MI: Zondervan.

Naugle, D. K. (2002). Worldview: The history of a concept. Grand Rapids, MI: William B. Eerdmans.

Noebel, D. A. (2001). Understanding the times. Colorado Springs, CO: Summit Press.

Olson, D. R. (1980). On the language and authority of textbooks. Journal of Communications, 30(1), 186-196.

Olster, N. (2006). Empires of the world: A language history of the world. New York, NY: Happer Perrenial.

Olthuis, J. H. (1985). On worldviews. Christian Scholars Review, 14(2), 153-164. 
‘Orange Revolution' has Disappeared from New History Textbooks. (2010).

Retrieved August 10, 2012, from

http://www.galinfo.com.ua/news/73243.html

Ovcharuk, O., \& Voytov, V. (2003). School textbook problems. In Reform strategy for education in Ukraine: Educational policy recommendations (pp. 167201). Kyiv, Ukraine: K.I.S.

Partridge, E. (1977). Base. In A short etymological dictionary of modern English (p. 222). London, England: Routledge.

Partridge, E. (1977). Faith. In A short etymological dictionary of modern English (pp. 1047-1048). London, England: Routledge.

Phillips, T.R., \& Okholm, D.L. (2001). A family of faith. An introduction to evangelical Christianity. Grand Rapids, MI: Baker Academic.

Pingel, F. (2006). Reform or conform: German reunification and its consequences for history Textbooks and Curricula. In J. Nicholls, J. (Ed.), School history textbooks across cultures (pp. 61-82). Oxford: Symposium Books.

Pingel, F. (2010). UNESCO guidebook on textbook research and textbook revision (2nd revised and updated ed.). Braunschweig, Germany: Georg Eckert Institute for International Textbook Research.

Polyzoi, E. and Nazarenko, T. (2004). A comparative snalysis of four case studies of education reform in Russia. World Studies in Education, 5(2), 65-80.

Popson, N. (2001). The Ukrainian history textbook: Introducing children to the Ukrainian nation. Nationalities Papers, 29, 325-350. 
Pütz, M., \& Verspoor, M. (2000). Introduction. In: M. Pütz \& M. Verspoor (Eds.), Explorations in linguistic relativity (pp. ix-xvi). Amsterdam, the Netherlands: John Benjamins Publishing Co.

Uchaykina, N.I. (2005). The Idea of perfection in light of the utopic space (Phylosophy and the future of civilization) (V.2). M., Russia: Nauka./ Учайкина, Н.И. (2005). Идея совершенствования в контексте утопического пространства (Философия и будущеее цฺивилизащии) (Т. 2). М.: Наука.

Redfield, R. (1952). The primitive world view. Proceedings of the American Philosophical Society, 96(10), 30-36.

Remnick, D. (1993). Lenin's tomb. The last days of the Soviet empire. New-York, NY: Random House.

Richards, J., \& Rodgers, T. (2001). Approaches and methods in language teaching. New York, NY: Cambridge University Press.

Rosch, E. (1978). Principles of Categorization. In E. Rosch \& B.B. Lloyd (Eds), Cognition and categorization (pp. 27-48). Hillsdale, NJ: Lawrence Erlbaum Associates, Publishers.

Saumure, K. \& Given, L. M. (2008). Data saturation. In L. M. Given (Ed.). The SAGE encyclopedia of qualitative research methods (Vol.1, pp. 195-196). Thousand Oaks, CA: Sage.

De Saussure, F. (1966). Course in general linguistics. (Wade Baskin, trans.). New York, NY: McGraw-Hill. (Original work published in 1916) 
Sire, J. W. (2004). Naming the elephant: Worldview as a concept. Downers Grove, IL: InterVarsity Press.

Serebrianikov, B. A., Kubriakova, E. S., \& Postovalova, V. I. (1988). The role of human factor in language: language and picture of the world. M., Russia: Nauka./ Серебрянников, Б. А.. Кубрякова, Е. С., \& Постовалова, В. И. (1988). Роль человеческого фактора в языке: Язык и картина мира. М.: Наука.

Smart, N. (1983). Worldviews. New York, NY: Charles Scribner's Sons.

Stein, R. H. (1994). A basic guide to interpreting the Bible: Playing by the rules. Grand Rapids, MI: Baker Books.

Strauss, A. L., \& Corbin, J. (1990). Basics of qualitative research: Grounded theory procedures and techniques. Newbury Park, CA: Sage.

Strauss, A.L., \& Corbin, J. (1998). Basics of qualitative research techniques and procedures for developing grounded theory (2nd ed.). London, England: Sage.

Sunderlin, W. D. (2003). Ideology, social theory, and the environment. Lanham, MD: Rowman \& Littlefield.

Talmy, L. (2000). Toward a Cognitive Semantics (Vol. I\&II). Cambridge: The MIT Press.

Thornberg, R., \& Chamaz, K. (2011). Grounded theory. In: S. D. Lapan, M. Quartaroli \& F. Reimer (Eds.), Qualitative research: An introduction to methods and designs (Vol. 37, pp. 41-67). San Francisco, CA: John Wiley/ Jossey-Bass. 
Trabant, J. (2000). How realistic are Humbolt's 'Weltansichten'? In: M. Pütz \& M. Verspoor (Eds.), Explorations in Linguistic Relativity (pp. 25-44). Amsterdam, The Netherland: John Benjamins Publishing Co.

Velychenko, S. (Ed.). (2007). Ukraine, the EU and Russia: History, culture and international relations. New York, NY: Palgrave.

Wallace, A.F.C. (1970). Culture and Personality. New York, NY: Random House.

Walsh, B. J., \& Middleton R. J. (1984). The transforming vision: Shaping a Christian worldview. Downers Grove, IL: InterVarsity.

Wanner, C. (1998). Burden of dreams: History and identity in post-Soviet Ukraine. University Park, PA: The Pennsylvania State University Press.

Wierzbicka, A. (1980). Lingua mentalis: The semantics of natural language. New York, NY: Academic Press.

Wierzbicka, A. (1996). Semantics: Primes and universals. Oxford, UK: Oxford University Press.

Wilhelm, G. M., \& Firmin, M. W. (2008). The Dayton agenda. Character education: Christian education perspectives. Journal of Research on Christian Education, 17, 182-198.

Wilson, A. (2002). The Ukrainians: Unexpected nation (3th ed.). London, England: Yale University Press.

Wolterstorff, N. (1984). Reason within the bounds of religion (2nd ed.) Grand Rapids, MI: Eerdmans Publishing Co.

Wright, N. T. (1992). The New Testament and the people of God. Minneapolis, MN: Fortress Press. 
Zajda, J. (2003). The politics of rewriting history. International Review of Education, 49(3\&4), 363-382.

Zajda, J. (2005). The politics of rewriting history: New school history textbooks in Russia. In J. Zajda (Ed.), The International handbook of globalisation and education policy research (pp. 693-716). Dordrecht, the Netherlands: Springer.

Zajda, J. (2007). The new history school textbooks in the Russian Federation: 19922004. Compare, 37(3), 291-306.

Zajda, J. (2009). Nation-Building, Identity and Citizenship Education: Introduction. In J. Zajda, H. Daun \& L. Saha, L. (Eds.), Nation-building, identity and citizenship education: Cross-cultural perspectives (Vol. 3, pp. 1-11). Dordrecht, the Netherlands: Springer. 